\title{
RBEP
}

\section{Letramento digital nas interações on-line: análise dos fóruns de discussão do programa de formação continuada em mídias na educação}

Luís Paulo Leopoldo Mercado

Rosana Sarita de Araújo

\section{Resumo}

Investiga como os níveis de letramento digital interferem nas interações on-line em fórum de discussão e tem como objetivo descrever as características dessa atividade e as habilidades necessárias para nela interagir qualitativamente. Categoriza os níveis de letramento digital em fórum de discussão a partir do domínio de habilidades necessárias para o uso dessa ferramenta de interação on-line. Analisa os níveis de letramento digital apresentados pelos cursistas nos fóruns desenvolvidos ao longo do programa Mídias na Educação, os materiais de estudo que subsidiaram as reflexões propostas nos fóruns e os dados coletados mediante a aplicação de questionário à amostra dos cursistas. O estudo indica que o letramento digital implica a composição de novos gêneros digitais e de novos eventos e práticas de letramento, que a educação on-line é potencializada pelo uso de ferramentas e ambientes interativos e que o fórum, como espaço de interação, é marcado pelo diálogo e pela aprendizagem colaborativa. A análise dos dados permite concluir que o nível de letramento digital do cursista interfere na dinâmica e na qualidade de sua interação nos fóruns de discussão, de modo que, quanto maior for seu letramento digital, mais relevantes serão suas intervenções.

Palavras-chave: letramento digital; interação on-line; fórum de discussão; educação on-line; mídias na educação. 


\section{Abstract \\ Digital literacy in online interactions: an analysis of discussion forums of the continuing education program in educational media}

Aiming to describe the characteristics of online interactions in discussion forums and to know the required capability to well interact there, this article investigates how the level of digital literacy interferes with these interactions. We categorize levels of digital literacy in a discussion forum based on the required abilities to make use of this tool. Then we analyze the digital literacy levels shown by students in forums developed for the program "Educational Media", the reference material that supported students' reflections in these forums and questionnaires answered by a students' sample. The paper suggests that digital literacy implies gathering new digital genres, new events and literacy practice, that online education is enhanced by the use of interactive tools and settings, and that the forum, as an interactive space, is characterized by dialogue and collaborative learning. Data analysis allows us to conclude that the student digital literacy level interferes with the quality of interaction and the dynamics in the discussion forums. So, the better is their digital literacy the more relevant are their interventions.

Keywords: digital literacy; online interaction; discussion forum; online education; educational media.

\section{Introdução}

A popularização dos meios de comunicação vem contribuindo para a evolução da educação a distância (EaD) alargando as possibilidades de interação, o que se reforça através da incorporação das tecnologias da informação e comunicação (TICs), com destaque para o uso da internet, que se constitui uma ferramenta mediadora de relevantes possibilidades pedagógicas, abrangendo entre estas as possibilidades de interações síncronas e assíncronas.

Os progressos da $\mathrm{EaD}$ adotando a internet como ferramenta são enriquecidos com a presença de ambientes virtuais de aprendizagem (AVA), na medida em que estes otimizam as possibilidades de fazer da EaD uma modalidade altamente competente nos processos de interação tanto quanto as realizadas presencialmente. Para isto, destaca-se a necessidade de que esses ambientes sejam ricos em recursos e ferramentas, a fim de 
viabilizar experiências diversas, coerentes com uma proposta de educação que valoriza a capacidade de pensar, de se expressar, de solucionar problemas e tomar decisões, que instiga a autonomia, a criatividade e o espírito investigador do aluno.

Diante destas transformações que norteiam a EaD, temos por consequência uma variação nos processos de interação. Se antes destas mudanças mais significativas a prática da EaD se concentrava nos padrões tradicionais de comunicação da modalidade escrita e oral - especialmente escrita -, que se realizava geralmente através de correspondência (carta social) e, mais tarde, através do sistema de comunicação analógico (fax, telefone), temos hoje, incorporadas a esta prática, as potencialidades das TICs, um sistema de comunicação digital que se configura em "novos" modelos de comunicação, os quais, ainda que se organizem pela base da escrita e oralidade, contam com novos gêneros e instrumentos.

Esse aumento das modalidades de interação é resultado do desdobramento de um "novo" fenômeno que o uso da internet fez surgir: o letramento digital. Com ele, a apresentação de dados informativos através do espaço virtual repercute na estruturação de práticas de interação específicas para esse ambiente, que manifesta e caracteriza uma ruptura nos padrões de interação linear e sistemática.

O letramento digital vem desvelar "novos" espaços de interação que repercutem na estruturação de "novos" espaços de escrita e, por consequência, na constituição de "novos" gêneros textuais (digitais). Mas, apesar da popularização do uso da internet no final da década de 90, os internautas não estão ainda totalmente familiarizados com estes espaços e gêneros, no sentido de explorar, em vista da permissividade dos espaços, uma linguagem que ultrapasse os limites tradicionais da comunicação sem perder de vista os fundamentos da gramática.

A crescente utilização de fórum de discussão nas interações da educação on-line como ferramenta de informação e comunicação parte da ideia de que, assim como o letramento se constitui em níveis, em função das habilidades do sujeito em desenvolver as práticas sociais de leitura e escrita (Ribeiro, V., 2004), também o letramento digital pode ser configurado em níveis relacionados às habilidades de interações no ciberespaço. A partir do programa Mídias na Educação, ${ }^{1}$ foi analisado se o nível de letramento digital do cursista interfere na dinâmica e na qualidade de sua interação nos fóruns de discussão, de modo que, quanto maior for seu letramento digital, mais relevantes serão suas intervenções.

Os objetivos deste estudo foram: descrever as características do fórum de discussão e as habilidades necessárias para nele interagir qualitativamente; categorizar os níveis (ou graus) de letramento digital em fórum de discussão, a partir do domínio de habilidades necessárias para o uso dessa ferramenta de interação on-line; e analisar o nível de letramento digital apresentado pelos cursistas nos fóruns do programa Mídias na Educação.

\footnotetext{
1 Programa desenvolvido no AVA e-ProInfo no período de setembro de 2006 a agosto de 2007, coordenado pela Secretaria de Educação a Distância (Seed) do Ministério da Educação (MEC) em parceria com a Secretaria de Estado da Educação e do Esporte (SEEE-AL) e a Universidade Federal de Alagoas (Ufal), na oferta do Estado de Alagoas. O programa, coordenado pela Universidade de Brasília (UnB), teve início com uma turma piloto no ano de 2005, com duração aproximada de seis meses, que formou os primeiros tutores para ingressar no acompanhamento do programa nos diversos Estados. Em Alagoas, a primeira oferta aconteceu no ano de 20062007.
} 


\section{Letramento digital}

Delineando a educação como um dos campos geradores dos conceitos sociais, é possível observar as mudanças que este espaço tem sofrido com a inserção das TICs, sobretudo no processo de educação escolar. Se desde a década de 90 despertamos para a evidência de que era necessária a formação de sujeitos letrados - exercício este que vai além da mera alfabetização -, com a imersão das TICs na sociedade, constatamos o imperativo de as práticas de letramento compreenderem também o letramento digital.

Conforme a diferença entre alfabetização e letramento vem sendo pontuada por Kleiman (1995), Soares (2000, 2002) e Tfouni (1995), é pertinente também destacar a diferença entre alfabetização digital e letramento digital: enquanto a primeira se caracteriza pelo uso das funções e ferramentas básicas computacionais, o segundo, em sua essência, compreende o exercício de práticas digitais letradas, efetivas e significativas que envolve o uso de diferentes e variadas ferramentas utilizadas como meio de buscar informação, comunicação a distância, diversão e fruição (Rojo, Barbosa, Collins, 2006).

No percurso da formação do sujeito, o processo de alfabetização é só o passo inicial para elevar o nível de letramento. Logo, a aquisição da leitura e da escrita mediada por prática e eventos de letramento possibilita ao sujeito o exercício das práticas culturais, sociais e historicamente estabelecidas. A capacidade de compreender e ultrapassar as fronteiras do texto inferindo sobre o discurso que o perpassa sinaliza o nível de letramento do sujeito, tal como afirma Xavier (2002, on-line): "a capacidade de enxergar além dos limites do código, fazer relações com informações fora do texto falado ou escrito e vinculá-las à sua realidade histórica, social e política são características de um indivíduo plenamente letrado".

Entretanto, para que o sujeito alfabetizado digitalmente atue na perspectiva do letramento digital, é necessário que ele avance da mera utilização funcional dos recursos computacionais para o patamar de interação, que se desdobra através do potencial discursivo do sujeito. Referimo-nos a uma utilização funcional associada à ideia de Almeida (2005), de que ler telas, apertar teclas, utilizar programas computacionais com interfaces gráficas, dar ou obter resposta do computador equivale à alfabetização digital funcional, semelhantemente como identificação das letras e decodificação do alfabeto equivale à alfabetização funcional.

Podemos até nos deparar com situações em que o sujeito em baixo nível de letramento digital utilize as ferramentas computacionais (tal como uma criança utilizando um software para colorir figuras ou montar cenário, ou um adolescente jogando um jogo de estratégia, ou ainda um adulto digitando uma receita e depois a imprimindo), mas certamente constatamos que o uso dessas ferramentas é mecânico e limitado e que tampouco desencadeia um processo de mudança "que permita ao sujeito reinventar seu quotidiano, bem como estabelecer novas formas de ação que se revelam em práticas sociais específicas e em modos diferentes de utilização da linguagem verbal e não-verbal" (Xavier, 2002, on-line). 
Neste sentido, o autor citado pontua que uma variável importante para o exercício do letramento digital é a apropriação do letramento alfabético pelo indivíduo, uma vez que nele se insere o domínio da leitura e a escrita de códigos e sinais verbais e não verbais. Logo, o letramento alfabético pode ser considerado um importante subsídio para o letramento digital.

As práticas e eventos de letramento espelham a influência da escrita na organização social, remetendo-se ao processo de difusão e controle da informação, intimamente ligada ao processo de comunicação. Diante destas características, a popularização das TICs potencializa estas práticas e eventos à medida que evidencia a leitura/escrita reinventando novas possibilidades de usos em espaços "novos" e/ou reelaborados, com características até então limitadas ou inexploradas.

Nessas novas práticas de leitura e escrita desencadeadas pelas TICs, constatamos a configuração de uma nova faceta do letramento, pois, maximizando as formas de letramento alfabético, é na esfera do letramento digital que elas dão suporte para o desencadear de interações muito mais profundas, fundamentadas "na lógica da multilinearidade, da heterogeneidade, interatividade, intertextualidade, interdisciplinaridade, do dialogismo e da polifonia" (Dias, Moura, 2006, p. 80).

Este aprofundamento nas interações é viabilizado pela integração da internet às TICs, a qual vem sendo caracterizada como uma das ferramentas mais eficientes na promoção de interações, pois, arquitetada sob os moldes de um novo espaço interativo, oferece ao leitor/escritor a fluidez de acesso com ilimitadas possibilidades de idas e vindas sobre infinitas informações.

Na internet, os conceitos espaciais e temporais revestem-se também de um novo significado com caráter flexível e volátil, no qual o concreto dá lugar ao virtual, compondo o cenário em que o letramento digital se desenvolve. Por estas peculiaridades, de acordo com Buzato (2007, p. 84), o letramento digital requer habilidades

[...] que têm a ver não apenas com saber manipular o computador, mas também com saber filtrar ou categorizar as informações, com olhar criticamente para um conceito e perguntar que referência está por trás, entre outras capacidades que desenvolvemos (ou deveríamos desenvolver) nos letramentos escolares.

O letramento digital implica o domínio de habilidades específicas para navegar na internet e interagir em seus diversos espaços, e estas habilidades se reportam às particularidades da leitura e da escrita na compreensão das também diferentes linguagens.

Apoiando-se nas características do ciberespaço, as práticas e eventos de letramento digital são assim mediadas por um conjunto de gêneros digitais que instigam o sujeito a lançar mão de novos processos cognitivos ajustáveis à dinâmica de interação desse espaço.

Neste sentido, o sujeito alfabeticamente letrado apresenta melhores "condições de se apropriar totalmente do letramento digital, pois os conhecimentos necessários para entender e acompanhar já foram apreendidos" 
${ }^{2}$ O conceito de hipertexto é aqui explorado segundo o referencial de Queiroz (2005, on-line) que o define como "um tipo de texto eletrônico no qual a escrita não é seqüencial". Ainda de acordo com a autora, "nesse tipo de texto há uma bifurcação que permite que o leitor eleja e leia através de uma tela de computador. Trata-se, na verdade, de uma série de blocos de textos interligados por nós, formando diferentes itinerários para o usuário".

${ }^{3}$ Etimologicamente, interação diz respeito à ação recíproca com mútua influência nos elementos inter-relacionados. Alguns autores aproximam os conceitos de interação e interatividade. Assim, para Silva (2000, apud Almeida, 2003, p. 203), "interatividade permite ultrapassar a condição de espectador passivo para a condição de sujeito operativo"
(Xavier, 2002, on-line), uma vez que o ciberespaço, além de utilizar a linguagem verbal e não verbal, alicerça-se nos princípios da leitura e da escrita, organiza-se através de uma rede de relações e interações que se materializa em forma de hipertexto digital.

$\mathrm{O}$ hipertexto ${ }^{2}$ antecede o suporte digital, consistindo basicamente em produções escritas que perpassam a não linearidade. Ana Ribeiro (2006) e Dias e Moura (2006) apresentam essa discussão referindo-se à caracterização da leitura hipertextual como um evento comunicacional e cultural que não se restringe apenas ao meio eletrônico, mas sim sendo constituído pelo modo de operar não linear, interativo, intertextual e heterogêneo - dessa forma, os suportes digitais apenas potencializam a construção de ambientes hipertextuais. Na perspectiva do letramento digital, é o hipertexto que subsidia o espaço de leitura e escrita, marcado essencialmente pela não linearidade.

O hipertexto é uma estrutura que suporta as relações e interações no ciberespaço; nele é observada a importância do letramento alfabético para a formação do letramento digital, uma vez que as habilidades de leitura e escrita, os suportes, os portadores de texto e os gêneros textuais são criados, resgatados e/ou reelaborados neste espaço.

As "transformações" que proporcionam o letramento digital são desencadeadas por este "novo" espaço da escrita que se caracteriza pela possibilidade de leitura multidimensionada e no qual a informação é disposta e organizada em forma de teia, podendo apresentar-se sob diversas linguagens (texto, imagem, som, animações).

Com o espaço da escrita sendo remodelado, diferentes habilidades despontam como necessárias, compreendendo que a linearidade e a sequenciação expandem-se para o formato do hipertexto; como prática do letramento digital, espera-se que o usuário extrapole a leitura metódica e crie competências ao pairar sobre uma profusão de textos e contextos, de articulá-los entre si e com outros que se encontram dispostos em uma rede ilimitada. Assim sendo, concorre para o letramento digital que o navegante, ao deparar-se com os mais diversos caminhos, apresente habilidade de fazer escolhas e de interagir com a informação.

Os avanços do letramento digital estão intimamente ligados aos modos operacionais que o hipertexto viabilizou nas habilidades de leitura e escrita. Neste sentido, o grande salto quantitativo e qualitativo do letramento digital concentra-se amplamente na possibilidade de interação ${ }^{3}$ com a informação e na comunicação.

O recurso da interação no espaço da internet é singular na possibilidade de comunicação e de compartilhamento. Enquanto esta possibilidade na modalidade presencial está encerrada nos parâmetros geográficos e temporais, bem como na materialidade dos suportes de textos e gêneros textuais e das ferramentas de comunicação, no ciberespaço esta possibilidade se expande, uma vez que as noções temporais e geográficas são ressignificadas, bem como a materialidade dos suportes/ portadores de textos e gêneros textuais e das ferramentas de comunicação transporta-se para a tela do computador e para a virtualidade. 
O tempo na esfera virtual se configura de acordo com a modalidade de interação; depende de a interação ocorrer em tempo real ou não. Neste sentido, o usuário pode envolver-se em interações síncronas ou assíncronas, o que está sujeito ao tipo de espaço e de ferramenta de comunicação a serem utilizados. No ciberespaço, as informações digitais são provisórias e plásticas, revestindo-se de um ritmo específico de pertinência imediata e de obsolescência acelerada (Ramal, 2002), o que reformula continuamente o letramento digital, mediante a possibilidade de a informação passar por constante atualização, diante da acessibilidade para alterá-la e disseminá-la em um curto espaço de tempo.

A interação no espaço da internet igualmente possibilita a comunicação e o compartilhamento potencializados pelos recursos de interação síncrona e assíncrona, em qualquer tempo e em qualquer lugar, bem como pela virtualidade dos suportes/portadores de texto, gêneros textuais e ferramentas de interação.

Conforme Silva (2005, 2007), a dinâmica da interação supõe autoria, participação e compartilhamento, o que vem instigar o exercício de uma relação dialógica e colaborativa, uma vez que o usuário, ao ser impelido a construir o seu próprio caminho, não só se guia pelos seus desejos, mas também pondera sobre as ações e reações de seus interlocutores. Neste movimento de interação, a mera transmissão da informação se dilata para a recriação, possibilitando a produção do conhecimento.

A interação na internet demarca as propriedades do dialogismo e da polifonia situadas por Bakhtin (1997); logo, o interagir não significa apenas enviar e responder mensagens, antes denota a possibilidade para o diálogo entre as diferentes vozes e em distintas direções, desencadeando relações de confronto e de negociação, num contínuo processo de construção e desconstrução de significados.

Essas possibilidades de interações flexíveis permitem superar a visão de comunicação unidirecional, na qual o emissor e o receptor estabelecem-se sobre o mesmo plano regido pela passividade; elas transformam e redimensionam a dinâmica de comunicação para um espaço de diálogo, de modo que, através da interação, emissor e receptor assumem igualmente os papéis de co-autores/co-criadores.

Os recursos multimídias e a flexibilidade de interação no hipertexto tornam o texto um conjunto de significantes. Assim, é possível observar que uma das características marcantes que difere o hipertexto do texto no papel é justamente o processo de construção do texto de um e de outro; a linearidade ou não linearidade é o princípio dessa construção textual.

À medida que avançamos no exercício do letramento digital repensamos os conceitos de textualidade e narrativa e a posição de um autor-leitor, uma vez que, diante da possibilidade de interações on-line, temos reconfigurada a noção de autoria ${ }^{4}$ quando a leitura se torna simultaneamente uma escritura.

Construído a partir de infinitas possibilidades, o hipertexto reconstitui a relação entre autor e leitor: este, ao navegar, incorpora as habilidades de escritor e se torna um co-autor, já que, com total autonomia,

\footnotetext{
4 Ricardo e Vilarinho (2006a) retomam a discussão de Fortunato (2003) pontuando que a autoria não se atrela apenas ao contexto social ou a um momento histórico; ela inclui a cultura midiática que define a sua forma de produção.
} 
5 A distinção entre escritor e autor fica ainda mais clara mediante o significado dos termos writter, aquele que escreve alguma coisa, e author, aquele cujo nome próprio dá identidade e autoridade ao texto (Chartier, 1999).

${ }^{6}$ Os ambientes virtuais distinguem-se dos gêneros textuais em vários sentidos, pois eles os abrigam e, por vezes, os condicionam. Não são domínios discursivos, mas domínios de produção e processamento textual em que surgem os gêneros (cf. Marcushi, Xavier, 2004)

7 "Os gêneros são formas sociais de organização e expressões típicas da vida cultural" (Marcushi, Xavier, 2004, p. 16). intervém nos caminhos e vias que o texto oferece. Essa autonomia, produto da abominação do monologismo e da não linearidade, possibilita ao autor-leitor ${ }^{5}$ avançar na produção do conhecimento a passos largos, em face da liberdade de explorar diversos espaços com diferentes funções: de autor-leitor, como editor, revisor e distribuidor.

As potencialidades de interação mediada por hipertextos, ao permitir a desmaterialização e a descorporização do texto, sinalizam então para a (re)descoberta do autor, na medida em que possibilita uma nova relação deste com sua obra, estimulado por ações de criação e autonomia pautadas na busca do sentir e da própria identidade (Ricardo, Vilarinho, 2006a, 2006b).

É possível observar que as práticas de interação on-line revolucionaram até mesmo a postura física do leitor e do escritor: antes com possibilidades limitadas de consultar simultaneamente os materiais de leitura e exercer a produção da escrita, estes têm hoje um espaço de leitura e escrita totalmente maleável; a estrutura de interação, a plasticidade de abrir janelas e caixas de textos concomitantemente, os recursos de formatação e fragmentação da informação, entre outros, definem um novo estilo de comportamento interativo seja do leitor e/ou escritor (autor).

\section{Gêneros digitais, ambientes virtuais e a escrita on-line}

A expansão do uso do hipertexto no que se refere a suas possibilidades de interação marca significativamente mudanças na recepção do texto, nos gêneros e nas funções deste mediante o conjunto de características que o delineiam entre escritor/autor e leitor, entre escritor/autor e texto e entre leitor e texto.

Cada tecnologia constitui-se de um espaço de escrita diferenciado, requerendo, portanto, modalidades de leitura e escrita e/ou de interação também diferentes. Como o espaço de escrita está intimamente relacionado com os gêneros textuais e os ambientes virtuais, ${ }^{6}$ entendemos que de novos espaços de escrita possivelmente emergem novos gêneros. ${ }^{7}$

$\mathrm{Na}$ tentativa de compreender como se caracterizam os novos gêneros digitais, Marcuschi e Xavier (2004) chamam a atenção para a identificação dos ambientes ou entornos virtuais em que estes se situam. Baseando-se nos âmbitos da internet, são classificados seis ambientes virtuais: 1) Ambiente web; 2) Ambiente e-mail; 3) Fóruns de discussão assíncronos; 4) Ambiente chat síncrono; 5) Ambiente mud; 6) Ambientes de áudio e vídeo (videoconferências). A esta classificação acrescentamos ainda o AVA.

Essa identificação norteia as distinções entre os ambientes virtuais e os gêneros, entendendo-se que: o ambiente suporta os gêneros; é nele que os gêneros digitais surgem; é através dele que os gêneros se desdobram; a ele os gêneros estão vinculados e/ou condicionados; são, portanto, entornos de produção e processamento textual. 
Localizados em um novo espaço enunciativo - o ciberespacial -, esses novos gêneros caracterizam-se pela combinação de recursos dos quais o produtor/locutor pode lançar mão para se comunicar produzindo uma "conversa-escrita" ou um "falar-escrito", de modo que essa produção resulta num texto híbrido (oralidade-escrita) e ilustrativo que tem por objetivo facilitar a redação de mensagens e assegurar a regulação dos diálogos na interação verbal e social na internet (Costa, 2005).

Os raciocínios empregados para "teclar" diferem daqueles utilizados para escrever a mão; logo, a comunicação síncrona ou assíncrona mediada por essas interfaces possibilita ao usuário da escrita teclada uma grande liberdade de comunicação.

Inevitavelmente, os gêneros digitais, ainda que associados a outros recursos de comunicação, estão apoiados na linguagem escrita; na internet, esta modalidade se configura como nova através da ação de "teclar", e a leitura se reformula através da "navegação". Nos novos suportes, o usuário da internet da primeira década dos anos 2000 escreve ou tecla para se comunicar, escreve para construir personagens, escreve para informar, escreve para construir relacionamentos, escreve para registrar pensamentos, escreve para dar sentido às suas experiências múltiplas e diversificadas (Costa, R., 2005). Também o sujeito lê - ou navega - numa leitura fluida, plástica, maleável, em que os textos não têm início nem fim. A partir de janelas que se abrem e se desdobram, ele toma posse da edição e formatação desses próprios textos, seja na produção ou recepção deles, bastando copiar, colar, recortar ou fragmentar e deslocar partes ou todo o conteúdo que compõe a mensagem.

Assim como o letramento está relacionado ao conjunto de práticas sociais orais e escritas de uma sociedade (Tfouni, 1995), também o letramento digital corresponde ao uso social da leitura e escrita. Logo, as práticas de letramento digital igualmente se desencadeiam no âmbito dos eventos de letramento, os quais, de acordo com Heath (1982), se caracterizam em situações em que a língua escrita é parte integrante da interação entre os participantes e de seus processos de interpretação.

Os eventos e práticas de letramento digital podem variar, ainda que se utilize o mesmo gênero digital. De acordo com Soares (2004, p. 107), a justificativa de a mesma ferramenta de interação para as práticas no cotidiano e no contexto educacional desencadear eventos e práticas de letramento digital diferentes se dá pelo fato de que

na vida cotidiana, eventos e práticas de letramento surgem em circunstâncias de vida social ou profissional, respondem a necessidade ou interesses pessoais ou grupais, são vividos de forma natural, até mesmo espontâneas; na escola, eventos e práticas de letramento são planejados e instituídos, selecionados por critérios pedagógicos, com objetivos predeterminados, visando à aprendizagem e quase sempre conduzindo a atividade de avaliação. 


\section{Letramento digital em fórum de discussão na educação on-line}

As práticas e eventos de letramento digital são fortemente resgatados e potencializados na modalidade de educação on-line, pois ela retoma as habilidades desenvolvidas para uso social da internet e soma novas habilidades para o exercício do letramento digital na perspectiva pedagógica. Podendo ser desenvolvida integralmente a distância ou na esfera semipresencial, a educação on-line ${ }^{8}$ apresenta um estreito vínculo com o letramento digital. Seja no AVA que se desenvolve nos materiais de apoio ao processo de ensino e aprendizagem, seja nos espaços de diálogo, as ações da educação on-line, na sua maioria, estão de alguma forma ligadas e dependentes do uso da internet.

As ferramentas de interação podem ser identificadas como um canal entre os usuários, no caso, os alunos, professores e demais envolvidos no processo de educação on-line - é através delas que os elos do processo de ensino e aprendizagem vão sendo construídos. Assim, é importante que os idealizadores das atividades a serem desenvolvidas na modalidade a distância através da educação on-line tenham a competência para adequar os objetivos, a metodologia e a avaliação às especificidades do contexto cibernético, não meramente transportando a prática educacional da educação presencial, mas ajustando-os às propriedades da educação on-line, a fim de garantir uma educação de qualidade.

Para que este conjunto de ferramentas tenha êxito, conforme as ações previstas, é válido reforçar a necessidade de familiarização por parte dos agentes envolvidos (alunos, monitores, tutores, professores, administradores) com a dinâmica do ambiente virtual. Neste sentido, espera-se que o conhecimento sobre as ferramentas de interação facilite o encaminhamento técnico requerido para cada ação (por exemplo, para participar de um chat, é preciso que o aluno saiba autonomamente escolher a sala, inserir seu nick, enviar mensagem) sem que prejudique o desempenho do autor e o conteúdo pedagógico da atividade proposta (por exemplo, ao participar do chat, o aluno deve ter domínio do modelo de organização das ideias naquele espaço).

A educação on-line é favorecida pela variedade de suportes e gêneros digitais mediadores de comunicação a distância, ambientes híbridos de aprendizagem. Neste contexto, o fórum é reconhecido como um valioso espaço que dispõe de conteúdos dinâmicos apoiados em bases de dados (Cunha, Paiva, 2003), viabilizando uma comunicação dialogada que se realiza assincronamente.

O fórum de discussão é um espaço de interação assíncrono norteado por um tema para debate entre os usuários (participantes interessados). A linguagem é organizada buscando encadear as ideias dos demais participantes junto a ideia central, explicitando a posição do participante diante da temática. O fórum é utilizado como ferramenta de interação assíncrona aberta a participações diversas; tratando de temáticas variadas, ele tem se caracterizado como um espaço de postagem de opiniões, de dúvidas,

\footnotetext{
8 A educação on-line é definida "como o conjunto de ações de ensino-aprendizagem desenvolvidas por meio de meios telemáticos, como a internet, a videoconferência e a teleconferência" (Moran, 2003, p. 39).
}

de argumentações, em que as pessoas levam ou não em consideração a 
fala do outro; no contexto educacional, ele é reconhecido como um rico espaço de interação que permite o diálogo entre os participantes em tempo assíncrono; seu conteúdo se remete a uma temática previamente explorada com os participantes; é caracterizado como um espaço de construção do conhecimento pautado na aprendizagem colaborativa; nele o público é mais restrito, delimitado entre os participantes da atividade pedagógica desenvolvida.

Suas especificidades de veicular a interação ${ }^{9}$ (que se realiza pelas relações entre os sujeitos através das ferramentas) e possibilitar a interatividade $^{10}$ (entendida como a relação direta dos sujeitos com os meios e interfaces) em tempo assíncrono tornam-no um ambiente pedagogicamente potencializador do processo de ensino e aprendizagem, na medida em que a comunicação assíncrona permite o exercício de síntese e objetividade sem abrir mão dos aspectos sintáticos da comunicação formal. Também permite que o acesso ao fórum seja feito oportunamente por cada participante em seu tempo mais propício, ocorrendo de cada membro participar em momento distinto, mas com acesso comum ao conteúdo de debate. Em virtude deste aspecto, o fórum permite que as reflexões se prolonguem no tempo, perdurando a temporalidade do debate em andamento.

Outra característica que torna o fórum de discussão atraente pedagogicamente é a possibilidade de os usuários simultaneamente comunicarem-se com vários outros interlocutores. Esta prática estimula o desenvolvimento da noção de grupo, de comunidade, levando o usuário ao processo de aprendizagem colaborativa. Ao aproximar os usuários na troca de informações, o fórum favorece a integração dos diálogos permeada pela criticidade que se estrutura na análise e negociação de sentidos.

O diálogo assíncrono em fórum on-line e a colaboração entre os participantes potencializam o processo de aprendizagem, concebido como processo social em que a construção do conhecimento deslocase da unidade de análise do indivíduo para a relação do indivíduo com o ambiente e a interação com os outros (muitos para muitos, aprendizagem em grupo). (Liden, Piconez, André, 2007, on-line).

A esfera de aprendizagem colaborativa pode ser significativamente desenvolvida com uso do fórum como espaço de construção coletiva. Na perspectiva de suporte, o fórum apresenta ferramentas que possibilitam réplicas e tréplicas das questões pontuadas, e, na maioria dos modelos, estas ferramentas se estruturam nas caixas de comentários. Esta opção é uma porta para a produção grupal, na qual todos os participantes têm a possibilidade de visualizar, analisar e inferir sobre as questões, dúvidas e respostas postadas.

É através da viabilização de conversas, troca de experiências, debate de ideias, questionamentos, relatos, demonstrações de solidariedade e construção coletiva de significados que o fórum, local de intensa interação, se traduz como uma verdadeira comunidade de aprendizagem conduzido à construção de novos saberes.

\footnotetext{
9 Interação entendida como a relação que os sujeitos estabelecem entre si através dos meios web, e-mail, chat, lista de discussão e fóruns (Liden, Piconez, André, 2007, on-line).

10 Interatividade vista como a relação direta dos meios e suas interfaces diretamente com o sujeito (idem).
} 
A construção do conhecimento é significativa não só pela via da colaboração, com a qual os participantes podem refletir sobre as mensagens postadas e somar as informações aos seus conhecimentos pessoais, mas também por este exercício estar intrínseco às necessidades, desejos e sentimentos de cada um.

Perante a dinâmica de interação no fórum, no qual as participações se tornam "públicas", os estudos de Cunha e Paiva (2003) apontam que ocorre o desenvolvimento de uma relação de afinidade, respeito e lealdade entre as partes que dialogam, de forma que todos se sentem muito à vontade para interferir, seja para contestar, concordar ou, ainda, levantar um novo questionamento a partir da fala do outro. Neste sentido, Bruno e Hessel (2007) situam que entre os participantes ocorre uma avaliação crítica das produções dos colegas, havendo mutuamente apoio e estímulo. De acordo com os autores citados, à medida que as interações vão sendo aprofundadas, demarca-se uma certa identidade no grupo,

que se manifesta na capacidade de dialogar com o outro, na capacidade de articular textualmente as questões de ordem emocional, na criação de uma imagem mental de si e do parceiro do processo comunicativo e na capacidade de criar uma sensação de presença on-line por meio da personalização de sua comunicação. (Bruno, Hessel, 2007, p. 4).

Chama-se a atenção para o modo como a informação é disponibilizada no fórum. De acordo com Cunha e Paiva (2003, p. 26), "as publicações vão constituindo uma espécie de testemunho histórico, esboçando uma ideia de evolução, facilitando a memória de fatos que contextualizaram o ensino/aprendizagem". Neste sentido, a estrutura do fórum delineia-se como uma trilha em que é possível observar o conteúdo ou tema desenvolvido, a progressão de cada interação, sua repercussão e sua culminância. Representa a materialidade da construção coletiva do conhecimento; é um guia que oferece o esboço da comunidade, de sua formação e sua manutenção.

Na educação on-line, de forma geral, os fóruns são desenvolvidos em AVA e tendem a ser fechados, delimitando a participação neles apenas dos participantes inscritos no curso; todavia, os fóruns também podem ser abertos, o que significa que seu desenvolvimento contará com a participação de usuários diversos. A opção por fórum fechado ou aberto será definida em função dos conteúdos e/ou temáticas a serem exploradas.

A concepção de trabalho colaborativo deve perpassar pela utilização do fórum. Para isso, é importante que o mediador/moderador se apóie em estratégias de familiarizar o grupo com as especificidades do fórum, posto ser um espaço de interação recentemente "novo" que agrega características ainda pouco percebidas aos participantes "novatos" no uso deste espaço.

Para que os participantes concebam o fórum como espaço de diálogo, para além de ambiente de inserção de mensagens ou de mera divulgação de problemas, é fundamental que o mediador/moderador valorize as interações e expanda a proposta de diálogo entre todos os participantes 
através de suas mediações, incentivando-os a revisitarem as postagens, a fim de ressignificarem o conhecimento socializado.

É interessante que os participantes se familiarizem com a dinâmica de interação no fórum, compreendendo que seu desenvolvimento segue uma ordem de procedimentos. É importante que primeiramente os participantes iniciem com a leitura das mensagens postadas, para, então, acrescentar repetidamente contribuições, dúvidas ou argumentações referentes ao tema central. A identificação das postagens deve acomodar títulos adequados que indiquem o seu foco. A expansão da temática pode ser concebida conforme a necessidade de ampliação do assunto, que certamente é favorecida pelas postagens de posições problematizadoras alargando a rede das discussões.

A caracterização do fórum como espaço dialógico e dialético condiz com as perspectivas da educação on-line, na medida em que possibilita o desenvolvimento de posturas significativas do aluno e do professor. $\mathrm{O}$ aluno incorpora o papel de pensador, que reflete, analisa e argumenta, na perspectiva de produzir o conhecimento coletivamente, enquanto o professor desce do pedestal a que a pedagogia tradicional o elevou e retoma o seu lugar como aprendiz, que, diante dos conhecimentos que já tem sistematizado, atua na qualidade de mediador, problematizando e alavancando o processo de ensino e aprendizagem. Colaborativamente, o professor deve observar que

\begin{abstract}
já não basta que os alunos adquiram conhecimentos; é necessário que se tornem competentes na busca e aquisição dos conhecimentos, passados e futuros; é importante que aprendam a viver e a trabalhar em sociedade; é indispensável que interiorizem valores estruturantes da humanidade! (Cunha, Paiva, 2003, p. 27).
\end{abstract}

A identificação do nível de letramento digital de um sujeito é observada na análise de seu desenvolvimento com práticas leitoras e escritoras imersas no ambiente digital, o que envolve observar "as diferentes capacidades e competências leitoras e de produção de textos e de linguagens, envolvidas na recepção e na produção de discursos em diferentes gêneros que circulam em diversos contextos, suportes e mídias contemporâneos" (Rojo, Barbosa, Collins, 2006, p. 111).

O letramento digital se caracteriza em diferentes níveis em função da variedade de habilidades adquiridas e desenvolvidas, destacando-se que essas habilidades estarão previamente relacionadas com os níveis de alfabetização. Desencadeia uma progressão no aperfeiçoamento dessas habilidades, considerando que estas não se esgotam nem se encerram no domínio de uma ferramenta e/ou gênero, na medida em que o processo de letramento digital é contínuo tal qual o letramento alfabético.

O exercício do letramento digital não está vinculado ao grau de instrução escolar, podendo ser desenvolvido por qualquer usuário, ascendendo não necessariamente no contexto escolar, mas mediante a exposição cada vez mais intensa desse usuário às práticas de letramento digital. 
É a partir do contato e da vivência prática pelo usuário que os níveis de letramento digital vão sendo apropriados, desenvolvendo-se com a familiarização dos novos tipos de leitura e escrita suportados pelo computador, bem como com a desenvoltura no uso das ferramentas de interação e na compreensão dos gêneros digitais.

No letramento digital é reconhecida uma infinidade de eventos e práticas de letramento das quais destacamos algumas que implicam indubitavelmente o processo de desenvolvimento dos seus vários níveis. São elas: reconhecer as funções das teclas, botões, portas/entradas, conectores, luzes indicativas e cabos do computador; conhecer dispositivos, acessórios e periféricos; conhecer programas; decodificar sinais e símbolos; fazer a leitura de palavras e ícones; executar a emissão de comandos; ter a habilidade de codificar, armazenar e recuperar informações; compreender a espacialidade e temporalidade virtual; fazer leitura hipertextual; reconhecer os suportes de textos digitais; conhecer ferramenta(s) de interação (síncrona e assíncrona); usar ferramenta(s) de interação (síncrona e assíncrona); reconhecer diferente(s) gênero(s) digital(ais); produzir diferente(s) gênero(s) digital(ais); saber e obedecer às regras de interação.

O domínio dessas habilidades sugere um parâmetro para qualificar os níveis de letramento digital, mas seria infindável classificar as diversas práticas letradas; logo observaremos que é a intensidade e desenvoltura com que estas habilidades são processadas e desenvolvidas pelo usuário que de fato define o grau de apropriação de letramento digital. Sugere-se então que a investigação do nível de letramento, para efeito deste estudo, considere no locus da pesquisa apenas as práticas letradas que estão sendo focadas, centrando-se na delimitação de parâmetros dessas práticas para avaliar as respectivas habilidades necessárias.

Para qualificar os níveis de letramento digital, deve-se considerar o grau desse exercício em relação ao domínio das habilidades necessárias para aquelas práticas investigadas - neste caso, para investigar as interações no fórum e definir a configuração de três níveis de letramento digital:

- Nível 1: estágio em que o usuário se aproxima de um uso mecânico e condicionado, ainda não reconhece integralmente as propriedades do gênero digital e o utiliza por associação do gênero impresso. Existe o apego a utilizar a ferramenta metodicamente, de uma única forma, restrito aos comandos que conhece.

- Nível 2: estágio em que o usuário já apresenta uma compreensão sobre o funcionamento e estruturação da ferramenta e as características que demarcam a linguagem de determinado gênero digital. Neste estágio, o usuário, de acordo com suas necessidades, começa a desenvolver autonomia testando e "arriscando" conhecer outras ferramentas e opções.

- Nível 3: estágio em que o usuário apresenta grande desenvoltura no uso das ferramentas de interação e na compreensão dos gêneros 
digitais, sendo-lhe familiar os "novos" tipos de leitura e escrita suportados pelo computador. Neste estágio, o usuário explora as ferramentas para conhecê-las, mesmo sem a necessidade de utilizá-las, e tem independência e autonomia para conduzir seu exercício de letramento digital.

Delimitada, a análise dos estágios e níveis de letramento digital é preponderante para avaliar uma prática definida num determinado tempo e contexto e com determinado público. Ela será investida para considerar o domínio de habilidades necessárias específicas daquelas práticas investigadas.

No caso do fórum de discussão, utilizado como ferramenta de interação, é possível considerar que seu uso desencadeia o exercício do letramento digital. Todavia, se tomado um determinado grupo de usuários em um determinado tempo e contexto, observa-se que este exercício pode ser caracterizado como heterogêneo mediante as diversas habilidades que o fundamentam.

Para avaliar o grau desse exercício de letramento digital no fórum, é preciso definir quais habilidades são pertinentes aos objetivos traçados para seu uso; logo, não há uma lista de habilidades comuns às investigações, que dependerão do foco de interesses a que a análise está voltada.

$\mathrm{Na}$ análise técnica de um fórum, por exemplo, algumas das habilidades e/ou categorias consideradas podem ser: o usuário sabe entrar no fórum; sabe localizar a questão norteadora; consegue postar seu comentário; especifica qual o tipo de sua postagem; sabe localizar outros participantes.

Numa análise pedagógica, podem ser observadas habilidades e/ou categorias como: existe coerência na resposta do cursista com a proposta de atividade sobre o conteúdo estudado; é explorada a interação no que se refere ao diálogo com os outros participantes; há marcas de interatividade no que se refere à usabilidade e acessibilidade do ambiente.

\section{Delimitação do estudo}

A interação na internet é perpassada pelos atos de ler e escrever; reconhece-se, através da etnografia virtual, a necessidade de compreender os significados dessas ações, explorando assim o material escrito que nela é registrado. Hine (2004, p. 66) aponta porque a investigação do material escrito é tão importante na etnografia virtual quanto a produção oral nas investigações etnográficas:

En vez de entender los textos como representaciones más precisas y detalladas de la realidad, podrían verse como materiales etnográficos que nos hablan de la comprensión que tienen sus autores de la realidad en la que viven. Los textos son parte importante de la vida en muchos entornos que los etnógrafos han venido visitando, e ignorarlos conllevaría una visión tremendamente parcial de las prácticas culturales. 
A dimensão ilimitada da internet traz o pesquisador para uma investigação multissituada, focada nas conexões e nas transformações, de modo que sua leitura não se dá a partir de um lugar (contexto local) concreto e delimitado, mas sobre o estudo dos fluxos e das estruturas que se realizam com as conexões. "Así, las etnografias on-line rompen con la noción de 'espacialidad' en las comunidades para concentrarse en los procesos culturales en vez de en los lugares físicos." (Hine, 2004, p. 78).

Nesta perspectiva, a etnografia virtual envolve a exploração das ferramentas utilizadas para interação, observando como estas se constituem e que transformações provocam, no sentido de mediarem as relações sociais que perpassam o espaço da internet.

A etnografia virtual tem como princípio compreender a essência dos fenômenos que se desdobram no ciberespaço; buscamos então, com a presente pesquisa, interpretar o contexto em que as interações on-line se desdobram e, a partir de uma leitura sistemática sobre como o letramento digital se configura, averiguar como se categorizam os níveis de letramento digital e como estes níveis interferem nos processos de interação travados em fóruns de discussão.

Como prática da etnografia virtual, analisamos, partindo da observação de um grupo de alunos da educação on-line, as diversas habilidades que constituem o letramento digital e as relações destas com o uso social das TICs.

A população do estudo teve como sujeitos 320 cursistas que participaram do programa Mídias na Educação. O curso constituiu-se de oito turmas, cada uma com 40 alunos, sendo cinco acompanhadas por tutores da Secretaria de Estado da Educação e do Esporte de Alagoas (SEEE-AL) e três por tutores da Universidade Federal de Alagoas (Ufal). A amostra escolhida envolveu 30 cursistas que participaram da turma da Ufal, a partir do requisito de ter concluído todos os módulos.

Para delimitar a amostra, optamos por sortear 10 cursistas para a investigação dentre os 30 concluintes da Ufal; tal medida se justificou pela elevada quantidade de dados disponíveis no AVA do curso, coletados por meio dos instrumentos de pesquisa, tornando-se inviável considerar uma amostra quantitativamente maior.

Foi feita a análise on-line dos fóruns desenvolvidos ao longo do programa Mídias na Educação, um de cada módulo escolhido através de sorteio, totalizando seis fóruns selecionados, observando-se as questões norteadoras de cada fórum e as respostas dos sujeitos-informantes, bem como a análise dos materiais de estudo (módulos) que subsidiaram as reflexões propostas nos fóruns.

Foram aplicados questionários via e-mail aos dez sujeitos-informantes delimitados na amostra, para colher informações detalhadas sobre o conhecimento dos alunos a respeito das TICs e as ferramentas, habilidades e estratégias utilizadas e desenvolvidas nas interações on-line.

Os procedimentos na análise on-line consistiram em averiguar a proposta do material de estudo oferecido pelo programa Mídias na Educação e os encaminhamentos para o desenvolvimento das atividades nos fóruns. 
Também se consideraram os perfis apresentados pelos cursistas na ficha de inscrição junto às respostas discriminadas no questionário aplicado referente ao conhecimento das TICs e as ferramentas, habilidades e estratégias utilizadas e desenvolvidas nas interações on-line. Com base na coleta de dados, é apresentada uma sistematização do perfil dos cursistas, da proposta dos módulos e da proposta dos fóruns.

Houve a coleta das intervenções dos sujeitos-informantes postadas nos fóruns selecionados analisando as interações e observando a existência de coerência entre a resposta do cursista e a proposta de atividade sobre o conteúdo estudado.

Para a análise do nível de letramento digital dos cursistas no uso de fórum de discussão, utilizando a base de dados coletada, analisamos as categorias que caracterizam o letramento digital: interação e interatividade.

No que se refere à formação profissional, todos têm vínculo direto ou indireto com a educação. Assim, as profissões exercidas são: professor das séries iniciais do ensino fundamental, do ensino médio, da educação superior e de pós-graduação, coordenador pedagógico, comerciário e engenheiro.

Os sujeitos-informantes declararam ter conhecimento das noções de informática, sendo este um dos requisitos exigidos para a seleção. Com o apoio do questionário, constatou-se que $7 \%$ dos sujeitos-informantes conceituam o seu conhecimento de informática referente ao uso de softwares destinados à edição de texto, planilha eletrônica e apresentação de slides como básico, 40\% o conceituam como intermediário e 53\% o consideram avançado.

A obrigatoriedade de os sujeitos-informantes terem uma conta de e-mail pressupõe seu conhecimento básico de interação na internet. Quanto às habilidades de navegação na internet no que se refere ao uso das ferramentas de interação on-line, $13 \%$ justificam que suas habilidades são restritas às ferramentas que conhecem, enquanto 47\% revelam que arriscam conhecer as ferramentas de acordo com as necessidades de usá-las e 40\% ultrapassam as incógnitas e exploram as ferramentas para conhecê-las mesmo sem a necessidade de utilizá-las.

A interpretação desses dados apresenta um cenário de cursistas envolvidos no processo de letramento digital, na medida em que já se encontram incluídos digitalmente ao dominarem habilidades mínimas para o exercício de manuseio dos softwares básicos de informática e de navegação na internet. O interesse em conhecer novas ferramentas de interação demonstra o avanço no nível de letramento digital, na medida em que buscam aprimorar suas habilidades e lançar mão de estratégias para interagir on-line com eficiência.

Todavia, mesmo os sujeitos-informantes tendo um conhecimento básico de informática e de navegação na internet, observa-se que a maioria deles (60\%) nunca tinha interagido em fórum de discussão e apenas 40\% já tinham participado de fóruns de discussão antes do programa.

Em vista da experiência de conhecer a dinâmica de interação no fórum de discussão, os sujeitos-informantes ${ }^{11}$ o caracterizaram ${ }^{12}$ enquanto

\footnotetext{
$\overline{11 \text { Representado pela sigla SI }}$ seguida do número de ordem na lista de sorteio.

12 Algumas respostas das categorias Caracterizações do fórum, Vantagens do fórum e Desvantagens do fórum foram suprimidas, devido à similaridade do conteúdo ou por não terem sido registradas pelos sujeitosinformantes.
} 
suporte na perspectiva de espaço (SI.1), local (SI.5), espaço construtivo (SI.6), espaço interativo (SI.7), campo facilitador (SI.3). Houve o reconhecimento do fórum como um ambiente propício à interação, como uma ferramenta de comunicação que permite:

- Interagir/Manter contato: com o tutor; com outros alunos; com várias pessoas.

- Expor/Refletir: ideias; questionamentos; concepções; pensamentos; pontos de vista; opiniões; dicas; conceitos.

- Trocar: ideias; informações.

- Propor: novos caminhos; novos questionamentos; caminhos esclarecedores; resolução de problemas.

- Compartilhar: experiências.

- Incitar: à pesquisa; ao aprimoramento da linguagem.

Apenas um sujeito-informante destaca as características do fórum como gênero, descrevendo-o como "Tipo de gênero fundado numa comunicação assíncrona." (SI.2).

Estes dados indicam que a experiência de interação no fórum proporcionou aos sujeitos-informantes o conhecimento das especificidades do ambiente enquanto suporte. Os 60\% que nunca haviam interagido em fórum tiveram êxito no que se refere à computação de uma postagem em cada fórum. No conhecimento do ambiente como gênero, não foram registradas observações quanto ao uso da linguagem e à estrutura sintática em que o fórum é organizado.

Os sujeitos-informantes evidenciaram os aspectos de temporalidade, espacialidade, aprendizagem colaborativa e ilimitada participação como as principais vantagens do fórum. Para cada aspecto são associadas as seguintes ações:

- Temporalidade: mais tempo para expor ideias; ferramenta assíncrona; poder parar e continuar; poder acessar a qualquer hora; não estar preso a horários; sem limite de tempo; trocar ideias ao mesmo tempo.

- Espacialidade: não estar preso a locais; trocar ideias em locais diferentes e distantes.

- Aprendizagem colaborativa: trocar ideias com várias pessoas; reflexões trocadas; partilhar saberes e adquirir novas experiências; o conhecimento pode ser descoberto e construído no coletivo; socializar experiências; aprofundar conteúdo.

- Ilimitada participação: diversidade de pontos de vista; poder opinar quantas vezes queira.

Estes dados sinalizam como os sujeitos-informantes se beneficiam do uso do fórum, posto que os aspectos de temporalidade e espacialidade virtual ampliam a participação do cursista, na medida em que favorecem o acesso comum ao conteúdo de debate a qualquer hora e de qualquer lugar 
conectado à internet. Em especial, a possibilidade de interação com vários sujeitos torna o fórum atraente como espaço de diálogo, acomodando reflexões, questionamentos, troca de ideias e de experiências.

Além destes aspectos, o uso do fórum favorece o desenvolvimento de uma aprendizagem colaborativa, pois nele é estimulada a integração dos diálogos, ao possibilitar a ampliação da noção de grupo, já que oferece espaço para a construção coletiva do conhecimento e perpassa nos participantes posturas de análise, respeito e negociação de sentidos.

Os sujeitos-informantes reconhecem como vantagem o uso do fórum por ser ele um espaço democrático em que as diversas posições podem ser apresentadas, não sendo discriminadas as diferentes opiniões. Nele, as intervenções são tomadas com o objetivo principal de diálogo.

Algumas das desvantagens de uso do fórum como espaço para desenvolvimento das atividades, na visão dos sujeitos-informantes, convergem para aspectos referentes a temporalidade, funcionalidade, interatividade e interação. Para cada aspecto são associadas as seguintes ações:

- Temporalidade: demora na postagem dos questionamentos; as respostas demoram um pouco; o tempo de resposta, por não ser imediato, gera uma maior ansiedade.

- Funcionalidade: às vezes o aplicativo não está disponível.

- Interatividade: não saber lidar com as novas tecnologias da informação.

- Interação: não interagir com os questionamentos dos demais; não criar comunidades colaborativas de aprendizagem; usar o espaço para clarificar dúvidas técnicas; mudança de foco no momento da discussão; dificuldade de entender as expressões corporais e os sentimentos dos colegas.

As informações apresentadas demonstram como o aspecto temporalidade pode ser interpretado tanto na perspectiva de vantagem como de desvantagem. No segundo, ele pode ser prejudicial devido à vulnerabilidade que apresenta. Por deixar o acesso livre e ilimitado, pode comprometer a participação no nível de assiduidade e pontualidade, influenciando no ritmo das interações. Por vezes, o cursista, ao demorar na postagem de suas intervenções, gera defasagem nas interações, como pode também aumentar o sentimento de ansiedade daqueles que esperam travar um diálogo.

Quanto ao aspecto funcionalidade, os dados sinalizam que os aspectos técnicos também influenciam no uso do fórum; por isso o seu funcionamento inadequado dificulta a dinâmica de interação. Neste nível de observação, igualmente podem ser incluídas as questões de interatividade que estão relacionadas ao uso das ferramentas do ambiente, uma vez que, se o cursista não se apropriou da usabilidade dessas ferramentas, pode comprometer a dinâmica de interação do fórum.

O aspecto interação é comprometido em relação ao nível de letramento digital dos cursistas, o que reflete na utilização do espaço do fórum, com 
divergências do seu real objetivo. Alguns se dispersam das discussões e dos diálogos e utilizam o fórum para comunicações individuais. Também a interação eventualmente é comprometida por questões relacionadas ao tipo de linguagem utilizada.

\section{Os fóruns do ciclo básico}

A proposta do programa Mídias na Educação foi estruturada para ser desenvolvida em três etapas: Ciclo Básico - com natureza de extensão; Ciclo Intermediário - com natureza de aperfeiçoamento; e Ciclo Avançado - com natureza de especialização. Para nossa pesquisa, selecionamos como locus o Ciclo Básico e sua $1^{\mathrm{a}}$ oferta. Considerado o ciclo inicial, o Ciclo Básico é o alicerce para a estruturação e o desenvolvimento dos demais ciclos; com carga horária de 120 horas, aborda a discussão sobre a utilização das mídias em diferentes concepções pedagógicas, os fundamentos e a aplicabilidade das principais mídias no ensino e na aprendizagem. Esta abordagem é contemplada no corpo de seis módulos subsequentes: Módulo 1 - Integração em Mídias na Educação; Módulo 2 - TV e Vídeo; Módulo 3 - Rádio; Módulo 4 - Material Impresso; Módulo 5 - Informática; e Módulo 6 - Gestão Integrada de Mídias na Educação.

O espaço de interação do fórum foi utilizado para o desenvolvimento de algumas atividades. Enquanto suporte, foram alocados no ciclo básico fóruns com temáticas específicas referentes ao conteúdo proposto para discussão de cada módulo. Para interagir nos fóruns de cada módulo, os cursistas acessavam a ferramenta "Interação - Fórum" (Fig. 1), optando por um fórum de interesse que estivesse ativado.

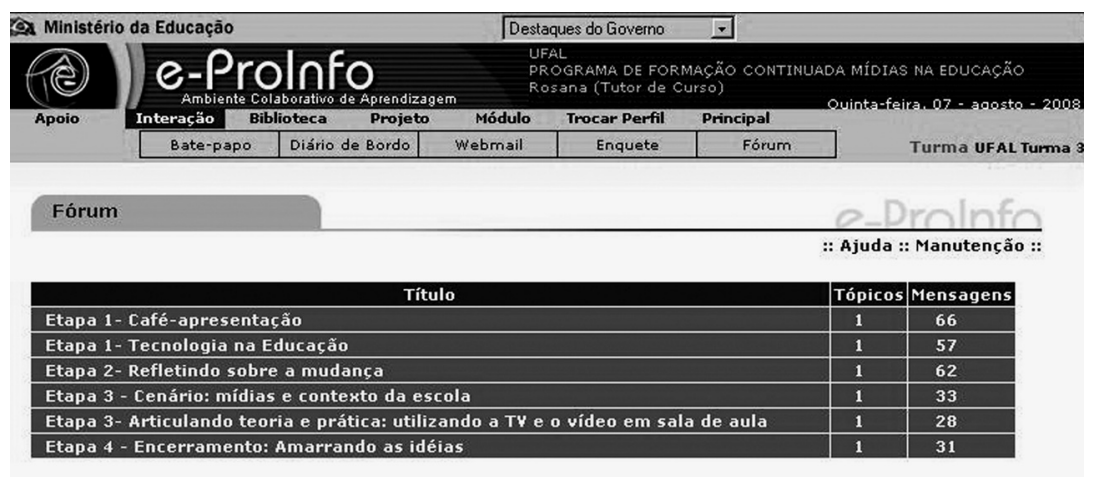

Figura 1 - Ferramenta "Interação - Fórum"

Ao clicar no título do fórum de interesse, o ambiente apresenta uma janela formatada para acomodar as interações (Fig. 2). Ao clicar no subtítulo, o usuário acessa as ferramentas acessíveis para formatação e envio de texto disponibilizadas em outra janela (Fig. 3). 


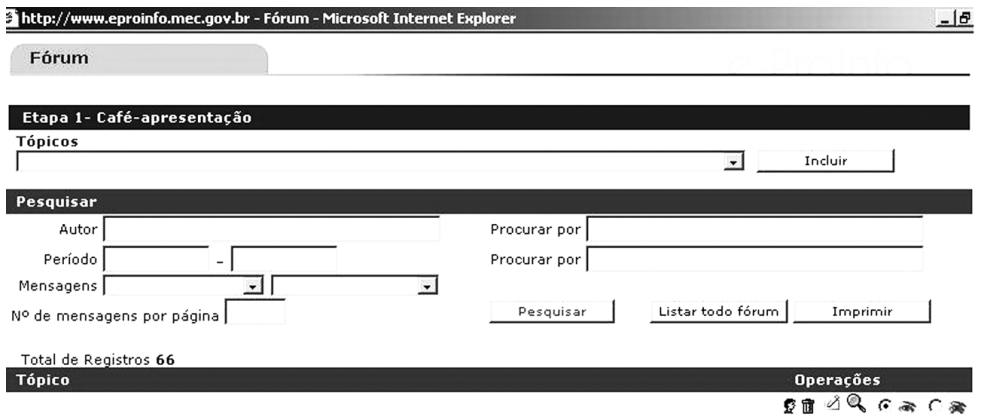

Figura 2 - Espaço de interação do fórum

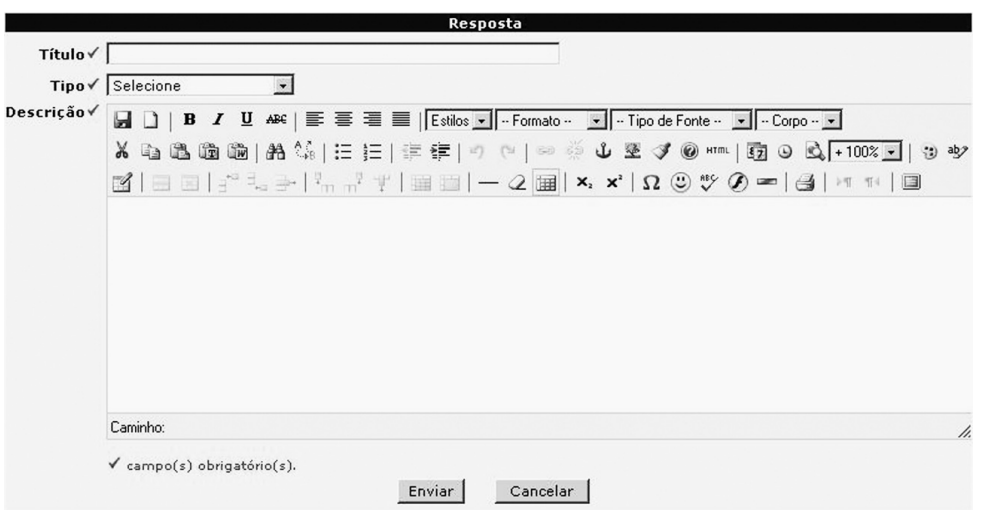

Figura 3 - Espaço de formatação e envio de texto

De acordo com a coleta de dados, selecionamos um fórum de cada módulo mediante sorteio, totalizando seis fóruns para compor a amostra on-line a ser analisada. Foram eles: 1 - Refletindo sobre a mudança; 2 - TV digital; 3 - Como implantar um projeto pedagógico com o rádio; 4 - A escrita e a leitura no hipertexto; 5 - Conectando; e 6 - Estratégias articuladoras.

A proposta do Módulo 1 - Integração em Mídias na Educação envolveu o debate sobre o tema Refletindo sobre a mudança. Os cursistas deveriam, a partir da leitura do material da etapa 2 do módulo, observar como o tema mudança vem acontecendo no dia a dia de cada um e avaliar como lidamos com a rapidez e abrangência das informações, com as novas formas de comunicação e com recursos tecnológicos que demandam novas maneiras de aprender.

No fórum sobre TV digital, referente ao Módulo 2 - TV e Vídeo, o objetivo foi o de que os cursistas pesquisassem e propusessem como poderia ser trabalhada a TV digital na escola para o desenvolvimento de um projeto com os alunos. Esperava-se que os cursistas discutissem suas propostas e os comentários feitos pelos colegas.

O Módulo 3 - Rádio acolheu o fórum de temática Como implantar um projeto pedagógico com o rádio. Observando que os cursistas nessa etapa acumulavam um grande volume de informações aprofundadas através das pesquisas, discussões e vivências, foi sugerida a reflexão sobre toda essa bagagem em relação ao contexto educacional em que trabalham, 
respondendo se já utilizaram algum programa ou trecho de programa de uma rádio na sala de aula com os alunos. Em caso de resposta negativa, solicitou-se que o cursista, baseado nos exemplos mencionados e na sua própria pesquisa, descrevesse as ações que poderiam ser realizadas (com as devidas adaptações) na escola ou espaço educativo no qual interage; já no caso de resposta positiva, foi proposto que o cursista mencionasse que atividades poderiam ser desenvolvidas além da leitura e interpretação do texto radiofônico. Para enriquecer a atividade com troca de experiências, o fórum abria espaço para que os cursistas discutissem também algumas atividades já realizadas com a programação das rádios ou propusessem novas atividades que pudessem ser desenvolvidas a partir da programação das rádios sintonizadas na sua região.

Avançando para o fórum A escrita e a leitura no hipertexto, proposto pelo Módulo 4 - Material Impresso, a proposta foi de que os cursistas refletissem e debatessem sobre: O que muda na alfabetização, no letramento, nos processos educacionais, na cultura digital? Como a escola pode lidar com a cultura do hipertexto? Como a internet está mudando nossa relação com a leitura e a escrita? O computador e a internet servirão de estímulo à leitura ou serão uma ameaça a ela? Por quê? Por que o hipertexto é subversivo? Que dificuldades os leitores encontram na leitura apoiada por suportes virtuais? Que vantagens e desvantagens podem ser apontadas em relação à leitura apoiada por suportes virtuais? O hipertexto elimina a ideia da autoria?

No Módulo 5 - Informática, o fórum analisado foi o Conectando. Ao observar que a internet pode ser uma ferramenta favorável para ensejar aprendizagem significativa, mas também tem perigos espreitando internautas inexperientes, esse fórum propôs o debate sobre que medidas de proteção poderiam ser tomadas para o seu uso eficiente e seguro e como ela poderia ser usada apropriadamente na educação. Neste sentido, solicitou-se que os cursistas discutissem os problemas e soluções que dizem respeito ao uso seguro da internet.

No Módulo 6 - Gestão Integrada de Mídias na Educação, o último fórum tomado para a amostra foi sobre Estratégias articuladoras, destacando as leituras indicadas e a análise sobre as experiências vivenciadas e conhecidas sobre o uso das TICs no contexto escolar. O fórum propôs que os cursistas procurassem levantar possíveis estratégias que pudessem ser utilizadas para integrar o uso das TICs de forma articulada entre os aspectos pedagógicos e administrativos, apresentando algumas sugestões.

\section{O letramento digital nas interações mediadas por fóruns no programa Mídias na Educação}

Os fóruns do programa Mídias na Educação utilizados como espaços acolhedores dos diálogos expressos pelos participantes em relação às temáticas estudadas e discutidas, ao possibilitar e instigar a interação e a interatividade, estimularam o exercício de habilidades remetentes ao letramento digital. Estas habilidades se iniciaram muito antes da 
participação no fórum, começando com acesso ao computador, conexão com a internet, localização do AVA, login com o programa, navegação nos conteúdos, acesso às ferramentas de interação, até o momento de localização, entrada e postagem no fórum.

O processamento destas diversas habilidades nos permite inferir que os cursistas possuem apropriadas algumas habilidades do letramento digital, pois já têm incorporadas as regras e convenções pertinentes ao uso da internet, suas propriedades e especificidades básicas, como a compreensão da lógica hipertextual e o conhecimento de alguns gêneros digitais. Com base nos dados extraídos do questionário aplicado, observou-se que 53\% dos cursistas investigados consideram seus conhecimentos de informática como avançado, 40\% intermediário e 7\% básico. Neste sentido, apenas a última parcela está se apropriando das habilidades ao longo do desenvolvimento do programa ao utilizar a internet.

No que se refere ao uso da internet, 13\% reconhecem-se no nível 1 de letramento digital, 47\% no nível 2 e 40\% no nível 3. Estes índices indicam que o exercício do letramento digital pelos cursistas antecedeu a participação no programa, de modo que a maioria diz utilizar razoavelmente as ferramentas de interação on-line, apresentando uma compreensão sobre seu funcionamento, sua estruturação e sua linguagem, e, de acordo com suas necessidades, começam a desenvolver autonomia testando e "arriscando" conhecer outras ferramentas e opções.

Considerando que 60\% dos cursistas nunca tinham interagido em fórum de discussão, definimos, para avaliar o nível desse exercício de letramento digital, alguns aspectos e habilidades pertinentes ao uso do fórum numa perspectiva pedagógica. O primeiro aspecto situa-se na análise das interações dos cursistas nos fóruns, observando a existência de coerência na resposta do cursista com a proposta de atividade sobre o conteúdo estudado. O segundo e o terceiro referem-se às habilidades de interação e interatividade, observando as categorias exploração da interação e existência de interatividade.

A partir das intervenções registradas nos respectivos módulos do programa Mídias na Educação, observamos se há coerência na resposta do cursista com a proposta de atividade sobre o conteúdo estudado.

Apesar de este aspecto ser de origem cognitiva, desencadeado a partir do letramento alfabético, pois envolve a capacidade de compreensão de ideias e inferência a partir de informações, entendemos ser pertinente a sua análise, uma vez que seu processamento subsidia as condições de interação no fórum e pode envolver o exercício de práticas e eventos de letramento digital, tais como o acesso aos materiais de estudo disponibilizados na internet, o uso de ferramentas de interação e o contato com gêneros digitais.

A coerência é subsídio para as condições de interação do fórum, considerando que, para haver interação, pressupõe-se algum conhecimento dos interlocutores sobre as ideias discutidas.

No fórum Refletindo sobre a mudança, referente ao Módulo 1 - Integração em Mídias na Educação, destacamos alguns questionamentos-síntese que sinalizam elementos de coerência com a proposta do fórum (Quadro 1). 
Quadro 1 - Questionamentos que sinalizam elementos de coerência com a proposta do fórum Refletindo sobre a mudança do Módulo 1

(continua)

\begin{tabular}{|c|c|}
\hline Intervenções & Questionamentos \\
\hline 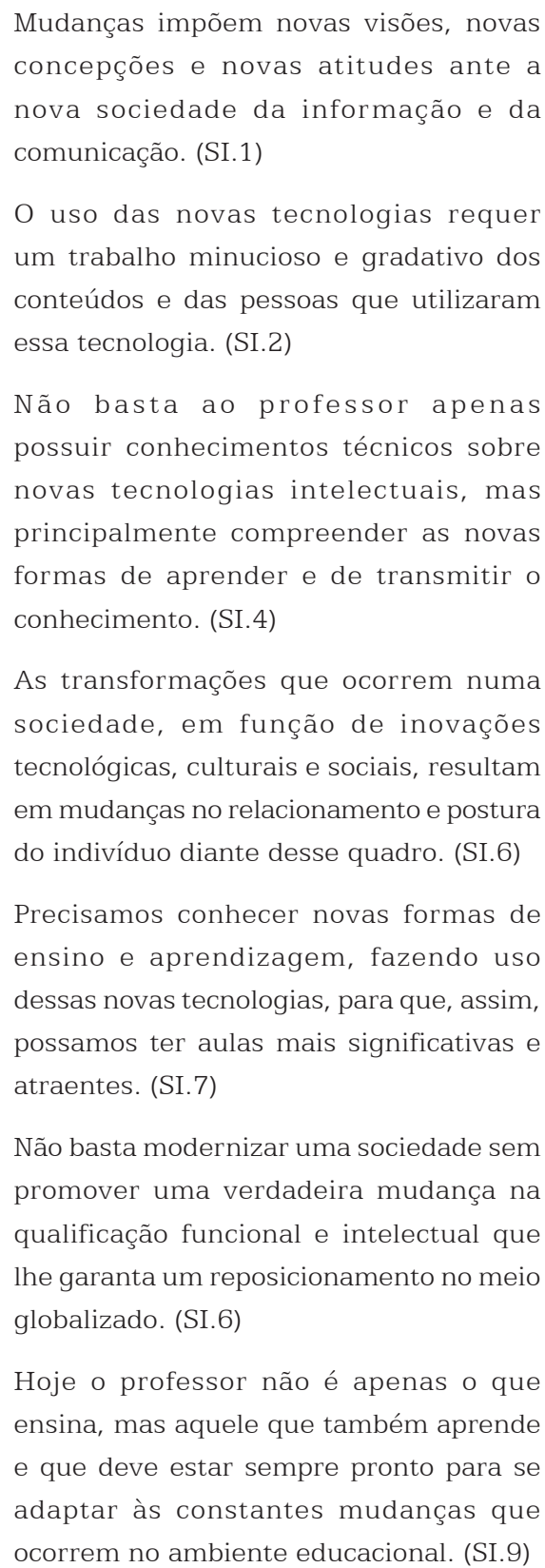 & $\begin{array}{l}\text { Com a efetiva integração das TICs } \\
\text { nas diversas esferas da vida, há } \\
\text { necessidade de re-elaboração de } \\
\text { novas atitudes, ações e valores. } \\
\text { A abertura para novos aprendi- } \\
\text { zados instiga um novo posiciona- } \\
\text { mento dos sujeitos. }\end{array}$ \\
\hline
\end{tabular}


Quadro 1 - Questionamentos que sinalizam elementos de coerência com a proposta do fórum Refletindo sobre a mudança do Módulo 1

(Continuação)

\begin{tabular}{|c|c|}
\hline Intervenções & Questionamentos \\
\hline 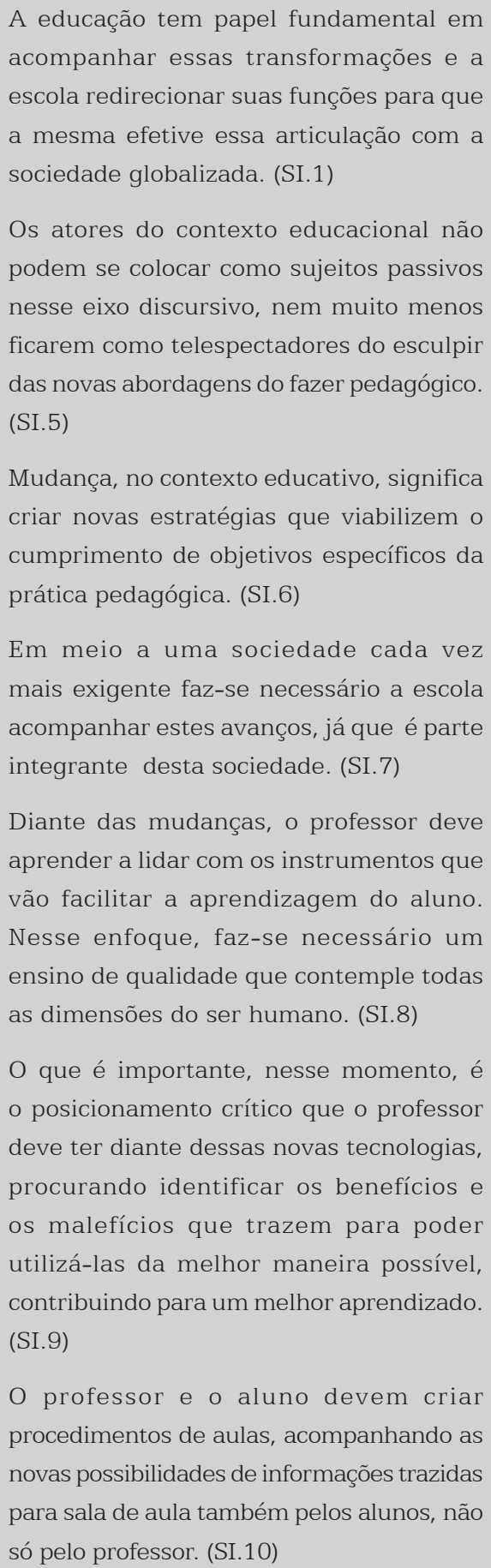 & $\begin{array}{l}\text { A rapidez com que a organização } \\
\text { social se modifica influenciada } \\
\text { pelas TICs, incide também } \\
\text { sobre a estrutura da educação, } \\
\text { desafiando a comunidade escolar } \\
\text { a compreender e investir em uma } \\
\text { nova forma de ensino. } \\
\text { Diante de um novo cenário, a } \\
\text { escola necessita interiorizar os } \\
\text { princípios da mudança e atuar na } \\
\text { formação crítica dos sujeitos para } \\
\text { intervirem nesta realidade. }\end{array}$ \\
\hline
\end{tabular}


Quadro 1 - Questionamentos que sinalizam elementos de coerência com a proposta do fórum Refletindo sobre a mudança do Módulo 1

(conclusão)

\begin{tabular}{|c|c|}
\hline Intervenções & Questionamentos \\
\hline $\begin{array}{l}\text { Temos feito apenas algumas adaptações, } \\
\text { pequenas mudanças. Precisamos extinguir } \\
\text { de uma vez por todas o "verniz" de } \\
\text { modernidade das nossas aulas e lançarmos } \\
\text { mão de aulas mais práticas e interativas } \\
\text { com o uso das novas tecnologias, e tudo isso } \\
\text { exige de cada um de nós, compromisso, } \\
\text { reflexão e ação! (SI.3) } \\
\text { A escola está tentando justificar o seu } \\
\text { "atraso" em virtude de ser tida como um } \\
\text { lugar "protegido" das transformações } \\
\text { sociais. (SI.) }\end{array}$ & $\begin{array}{l}\text { A necessidade de mudança no } \\
\text { contexto escolar apresenta- } \\
\text { se urgente e tarda em função } \\
\text { dos obstáculos que não são } \\
\text { superados. }\end{array}$ \\
\hline $\begin{array}{l}\text { As TICs são necessárias, mas também } \\
\text { precisamos ficar atentos ao uso que delas } \\
\text { fazemos. (SI.1) }\end{array}$ & $\begin{array}{l}\text { O uso das TICs deve se processar } \\
\text { como meio, recurso, ferramenta, a } \\
\text { potencializar a prática pedagógica } \\
\text { e não como fim. }\end{array}$ \\
\hline $\begin{array}{l}\text { A presença da tecnologia da informaçãoé um } \\
\text { fato irrefutável no mundo contemporâneo } \\
\text { da sociedade e principalmente do processo } \\
\text { de ensino-aprendizagem. (SI.5) }\end{array}$ & $\begin{array}{l}\text { A mudança é um processo } \\
\text { inevitável e irreversível. }\end{array}$ \\
\hline
\end{tabular}

Os sujeitos-informantes aprofundam suas reflexões com a apresentação de experiências e de ponto de vista fundamentando-se nas leituras e correlacionando-as com a prática. Estas constatações demonstram coerência nas respostas, pois há uma lógica nas reflexões postadas em face da questão norteadora do fórum, que solicitava aos sujeitos-informantes observarem como o tema mudança vem acontecendo no dia a dia de cada um e avaliarem como lidam com a rapidez e abrangência das informações e com as novas formas de comunicação e recursos tecnológicos que demandam novas maneiras de aprender. Assim, os sujeitos-informantes se remetem a sua prática e postura profissionais analisando como a inserção das TICs vem repercutindo na sociedade, na educação e, sobretudo, na escola.

Avançando para o fórum TV digital, do Módulo 2 - TV e Vídeo, destacamos algumas reflexões que sinalizam coerência com a proposta do fórum, já que produzem questionamentos que enfatizam as formas de trabalhar com a TV digital na escola. 


\section{Quadro 2 - Questionamentos que enfatizam as formas de trabalhar com a TV digital na escola e que sinalizam elementos de coerência com a proposta do fórum TV digital, do Módulo 2}

(continua)

\begin{tabular}{|c|c|}
\hline Intervenções & Questionamentos \\
\hline $\begin{array}{l}\text { A TV digital, depois de implantada e } \\
\text { devidamente conhecida, vai abrir novas } \\
\text { possibilidades e horizontes para a educação, } \\
\text { pois possibilita ao público uma participação } \\
\text { em tempo real, ou seja, no momento que a } \\
\text { programação está sendo exibida. (SI.1) } \\
\text { A TV digital permite essa interação tal qual } \\
\text { fazemos hoje na internet. (SI.3) } \\
\text { A qualidade da imagem vai fascinar ainda } \\
\text { mais o telespectador, e a escola deve } \\
\text { trabalhar o aluno para vislumbrar esse } \\
\text { encantamento sem perder o referencial } \\
\text { crítico dos programas televisivos. (SI.4) } \\
\text { Essa nova tecnologia nos possibilita uma } \\
\text { maior interação como mundo da programação } \\
\text { televisiva, além de ter uma maior qualidade } \\
\text { tanto no aspecto de imagem e som. (SI.5) } \\
\text { Ela proporciona transmissão e recepção de } \\
\text { maior quantidade de conteúdo por uma mesma } \\
\text { frequência, podendo atingir o alvo de muito alta } \\
\text { qualidade na imagem, entre outros. (SI.7) }\end{array}$ & $\begin{array}{l}\text { A TV digital vem favorecer } \\
\text { o canal de interação entre } \\
\text { público e programação. } \\
\text { A qualidade da imagem e do } \\
\text { som da TV digital envolve } \\
\text { o público e instiga a sua } \\
\text { utilização. }\end{array}$ \\
\hline $\begin{array}{l}\text { A TV digital é também um desses } \\
\text { instrumentos de grande potencial educativo, } \\
\text { que de forma inovadora transforma educando } \\
\text { e educadores em produtores de cultura } \\
\text { e conhecimento, extinguindo o papel de } \\
\text { simples consumidores passivos, e a escola } \\
\text { deve ser pólo dessas conexões. (SI.2) } \\
\text { Com o uso da TV digital na escola, abre-se } \\
\text { um leque de possibilidades de interação e } \\
\text { exercício da cidadania, onde o receptor passa } \\
\text { a ser agente da sua própria história. (SI.2) } \\
\text { As novas tecnologias influem diretamente } \\
\text { na educação das pessoas, como: costumes, } \\
\text { linguagens. (SI.3) }\end{array}$ & $\begin{array}{l}\text { A TV digital pode incidir } \\
\text { sobre o processo de ensino e } \\
\text { aprendizagem e no exercício } \\
\text { da cidadania. } \\
\text { Com a inserção da TV digital, } \\
\text { enfatiza-se a necessidade de } \\
\text { formação continuada para } \\
\text { conhecer as especificidades da } \\
\text { TV digital. } \\
\text { O uso da TV abre um leque } \\
\text { para a discussão de temas } \\
\text { variados. }\end{array}$ \\
\hline
\end{tabular}




\section{Quadro 2 - Questionamentos que enfatizam as formas de trabalhar com a TV digital na escola e que sinalizam elementos de coerência com a proposta do fórum TV digital, do Módulo 2}

(continuação)

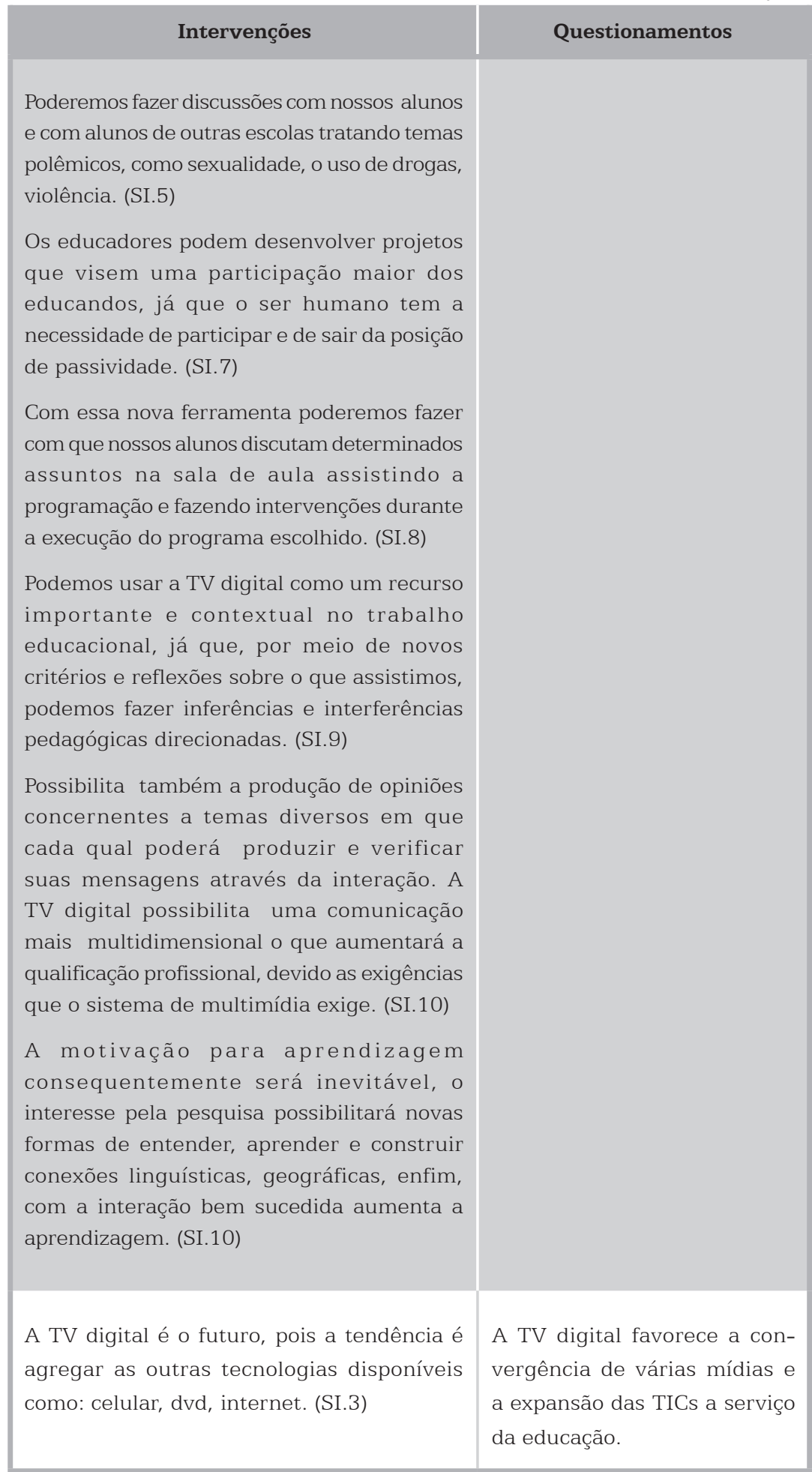




\section{Quadro 2 - Questionamentos que enfatizam as formas de trabalhar com a TV digital na escola e que sinalizam elementos de coerência com a proposta do fórum TV digital, do Módulo 2}

(conclusão)

\begin{tabular}{|c|c|}
\hline Intervenções & Questionamentos \\
\hline $\begin{array}{l}\text { Educar através da nova TV vai exigir que } \\
\text { educadores desenvolvam atividades de ma- } \\
\text { neira interdisciplinar, na tentativa de integrar } \\
\text { experiências anteriores e abrir caminhos para } \\
\text { questionamentos futuros. (SI.7) }\end{array}$ & $\begin{array}{l}\text { A TV digital recria a pos- } \\
\text { sibilidade de trabalho } \\
\text { interdisciplinar. }\end{array}$ \\
\hline
\end{tabular}

Constatamos nas intervenções a preocupação dos cursistas em encadear suas ideias de forma clara e consistente, fundamentando-se em leitura, compreensão e inferência sobre a temática explorada. Verificamos as expectativas dos sujeitos-informantes em efetivar suas pretensões quanto ao uso da TV digital. Pautados em conhecimento teórico das possibilidades da TV digital, eles descrevem oportunidades de integração desta mídia, destacando as potencialidades e cuidados que serão gerados.

No fórum Como implantar um projeto pedagógico com o rádio, do Módulo 3 - Rádio, detectamos os seguintes questionamentos que sinalizam coerência com a proposta da atividade sobre o conteúdo estudado (Quadro 3).

Quadro 3 - Questionamentos que sinalizam coerência com a proposta da atividade sobre o conteúdo estudado no fórum Como implantar um projeto pedagógico com o rádio, do Módulo 3

(continua)

\begin{tabular}{|c|c|}
\hline Intervenções & Questionamentos \\
\hline $\begin{array}{l}\text { O rádio na escola é mais uma ferramenta que } \\
\text { proporciona o conhecimento e nós educadores } \\
\text { não podemos se omitir deste trabalho. (SI.1) } \\
\text { O rádio em sala de aula pode dinamizar e oferecer } \\
\text { interação entre os alunos e a comunidade em } \\
\text { geral. Podemos muito bem fazer projetos de } \\
\text { divulgação de eventos na escola, simulados, tira } \\
\text { dúvidas, entrevistas e vários problemas sociais } \\
\text { existentes na comunidade, o que não falta são } \\
\text { ideias e orientações nesse módulo. (SI.5) } \\
\text { É notória a importância da ferramenta Rádio } \\
\text { na prática pedagógica, com sua utilização o } \\
\text { desenvolvimento lógico-discursivo se amplia } \\
\text { de forma gradativa e concreta tornando claro } \\
\text { e visível resultados positivos referentes ao } \\
\text { processo de aprendizagem. (SI.10) }\end{array}$ & $\begin{array}{l}\text { O rádio como mais uma } \\
\text { possibilidade de recurso } \\
\text { pedagógico. }\end{array}$ \\
\hline
\end{tabular}


Quadro 3 - Questionamentos que sinalizam coerência com a proposta da atividade sobre o conteúdo estudado no fórum Como implantar um projeto pedagógico com o rádio, do Módulo 3

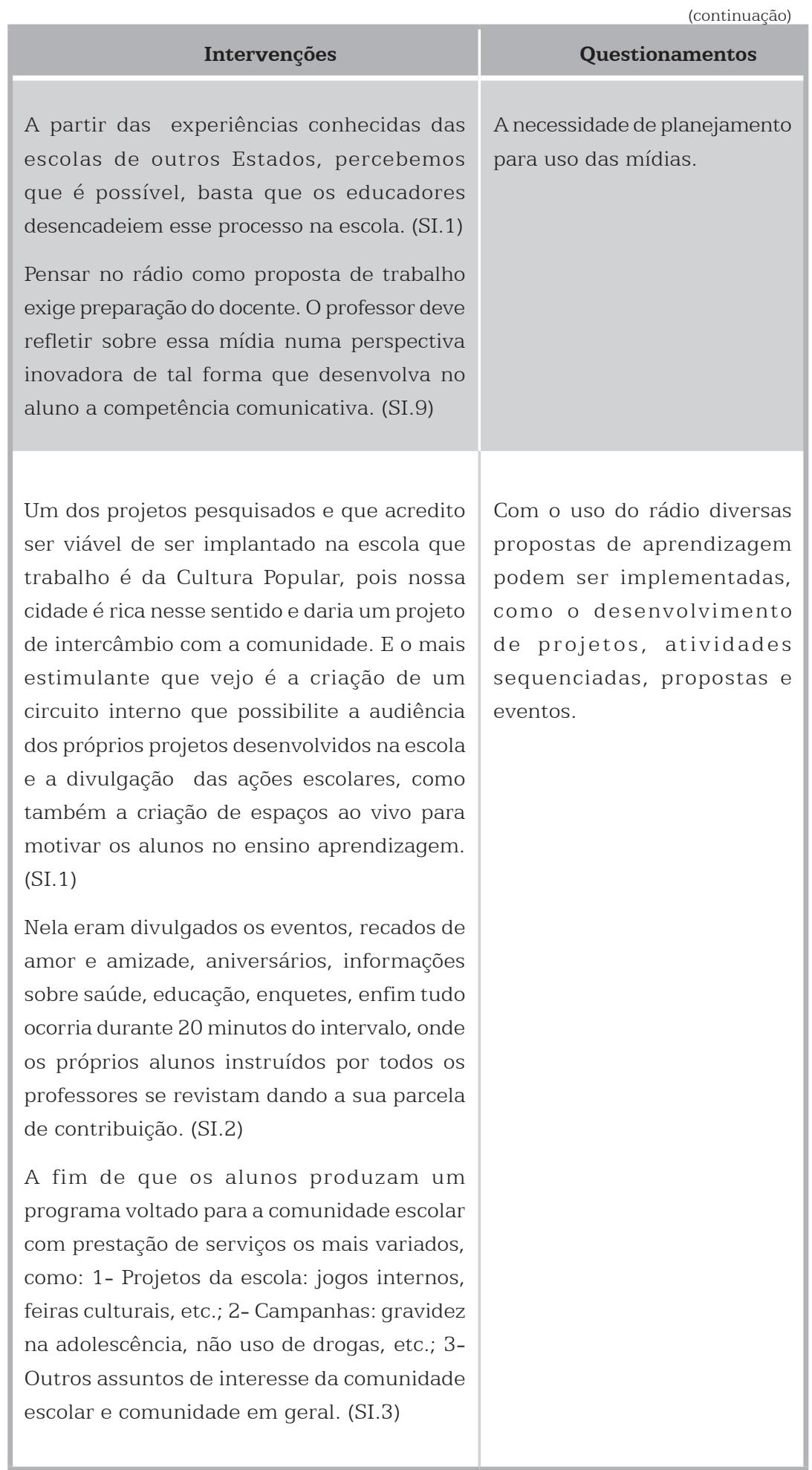


Quadro 3 - Questionamentos que sinalizam coerência com a proposta da atividade sobre o conteúdo estudado no fórum Como implantar um projeto pedagógico com o rádio, do Módulo 3

\begin{tabular}{|c|c|}
\hline Intervenções & Questionamentos \\
\hline $\begin{array}{l}\text { Gostaria de iniciar uma rádio em minha escola } \\
\text { que se enquadraria dentro da categoria restrita, } \\
\text { para ser transmitida informações educativas na } \\
\text { hora do recreio es alunos seriam os divulgadores } \\
\text { destes saberes. Outra ação a ser desenvolvida } \\
\text { com os alunos seria a análise de uma rádio, para } \\
\text { verificar a programação classificando o conteúdo } \\
\text { da mesma em educativa, informativa ou de } \\
\text { entretenimento. Surgiria também a idéia de } \\
\text { fazer uma enquete com os alunos a respeito da } \\
\text { importância das notícias transmitidas via rádio, } \\
\text { a frequência que utilizavam e outras coisas } \\
\text { referentes a criticidade ao ouvir um determinado } \\
\text { som. (SI.4) } \\
\text { Iniciamos com uma enquete junto aos alunos } \\
\text { para saber qual a opinião sobre o assunto. } \\
\text { Em seguida, incentivamos a ouvirem as } \\
\text { rádios comerciais, através de comentários } \\
\text { (...). O próximo passo é realizar alguns ensaios } \\
\text { preliminares. As informações podem ser } \\
\text { gravadas e reproduzidas com micro system ou } \\
\text { utilizar o sistema de som da própria instituição, } \\
\text { caso haja. É importante abrir um espaço } \\
\text { para sugestões e, então, criar a rádio escolar } \\
\text { universitária. Todos irão sentir-se valorizados e, } \\
\text { também, responsáveis pelas idéias implantadas. } \\
\text { Veja algumas sugestões no meu relato. (SI.6) } \\
\text { A criação de uma rádio no ambiente da escola } \\
\text { deve constar de variados programas que } \\
\text { despertem e motivem todos para a educação, } \\
\text { ou seja, programas de esclarecimentos sobre } \\
\text { diversificados assuntos prioritários, como sexo, } \\
\text { gravidez, drogas, doenças, estes que muitas } \\
\text { vezes são tratados como tabus e quase não são } \\
\text { discutidos, propagação de eventos na escola, } \\
\text { tudo isso sempre priorizando o aluno, fazendo } \\
\text { como sinta-se autor e ator. (SI.8) }\end{array}$ & \\
\hline $\begin{array}{l}\text { Levando os alunos a produzirem os } \\
\text { programas, estamos criando condições } \\
\text { para um aprendizado eficaz, pois é preciso } \\
\text { pesquisa e dedicação nessa produção. (SI.3) }\end{array}$ & $\begin{array}{l}\text { A inserção do rádio na escola } \\
\text { favorece a motivação dos } \\
\text { alunos. }\end{array}$ \\
\hline
\end{tabular}


Quadro 3 - Questionamentos que sinalizam coerência com a proposta da atividade sobre o conteúdo estudado no fórum Como implantar um projeto pedagógico com o rádio, do Módulo 3

\begin{tabular}{|c|c|}
\hline Intervenções & Questionamentos \\
\hline $\begin{array}{l}\text { O rádio é a mídia que possui maiores } \\
\text { alcance e poder de penetração na sociedade. } \\
\text { Promove o intercâmbio cultural, divulgação e } \\
\text { mobilização na emoção transmitida pela voz } \\
\text { do locutor. (SI.7) }\end{array}$ & $\begin{array}{l}\text { O rádio como uma das mídias } \\
\text { de grande poder de penetração } \\
\text { na sociedade. }\end{array}$ \\
\hline $\begin{array}{l}\text { O conhecimento aprendido na escola viajaria } \\
\text { para fora dos muros da escola, já que os } \\
\text { alunos estariam exercitando a oralidade, } \\
\text { a criatividade em produzir e divulgar o } \\
\text { conhecimento. (SI.4) } \\
\text { Desenvolvi a prática de ouvir rádio e percebi a } \\
\text { importância da oralidade informativa. (SI.7) } \\
\text { Educar, através do rádio, é integrar e } \\
\text { motivar as pessoas ao desenvolvimento de } \\
\text { seu potencial intelectivo, da sua capacidade } \\
\text { racional e emocional de interpretação e } \\
\text { imaginação. (SI.7) }\end{array}$ & $\begin{array}{l}\text { A oralidade é valorizada na } \\
\text { ação pedagógica que utiliza o } \\
\text { rádio como recurso. } \\
\text { A possibilidade de explorar } \\
\text { diversas linguagens e } \\
\text { conteúdos promovendo o } \\
\text { intercâmbio cultural. } \\
\text { O rádio como instigador no } \\
\text { desenvolvimento da emoção e } \\
\text { imaginação. }\end{array}$ \\
\hline
\end{tabular}

Os cursistas já se encontram mais maduros quanto à implementação de propostas inserindo o uso das mídias, logo apresentam um olhar mais apurado e crítico quanto às possibilidades de uso do rádio na escola. Os conhecimentos produzidos com apoio da literatura e das discussões anteriores encaminham reflexões detalhadas de como implantar a mídia na escola e quais propostas já estão sendo realizadas.

Ainda que muitos cursistas não tenham vivenciado a experiência de inserir o rádio na escola, eles apresentam um conhecimento lógico quanto ao planejamento de futuras ações e demonstram coerência em suas propostas e considerações, quando articulam as necessidades da realidade escolar com as especificidades que o desenvolvimento do trabalho com o rádio requer.

Continuando com o fórum A escrita e a leitura no hipertexto, do Módulo 4 - Material Impresso, destacamos algumas interações apontando os elementos de coerência através dos seguintes questionamentos (Quadro 4). 


\section{Quadro 4 - Questionamentos que sinalizam coerência com a proposta da atividade sobre o conteúdo estudado no fórum $A$ escrita e a leitura no hipertexto, do Módulo 4}

\begin{tabular}{|c|c|}
\hline Intervenções & Questionamentos \\
\hline $\begin{array}{l}\text { A hipertextualidade, pode-se afirmar, é } \\
\text { uma nova linguagem que permite uma } \\
\text { comunicação em rede estabelecendo várias } \\
\text { conexões ao mesmo tempo, uma amplitude } \\
\text { ora surpreendente. (SI.1) } \\
\text { O hipertexto possibilita a meu ver uma } \\
\text { interação completa e complexa do aluno leitor, } \\
\text { que não se detém apenas a um único link, mas } \\
\text { a vários, tornando assim a pesquisa e estudo } \\
\text { mais completo. (SI.2) } \\
\text { O hipertexto, pela sua forma não-linear, } \\
\text { possibilita diferentes escolhas para leituras e } \\
\text { interferências on-line. A tela do computador, } \\
\text { como novo espaço de escrita, traz mudanças } \\
\text { significativas nas variadas formas de interação } \\
\text { entre o ser humano e o conhecimento. (SI.8) }\end{array}$ & $\begin{array}{l}\text { A maleabilidade do hipertexto, } \\
\text { diante da sua não linearidade } \\
\text { e não sequenciação, permite } \\
\text { a o s ujeito explorar a } \\
\text { interatividade e ter acesso a } \\
\text { infinitas informações. }\end{array}$ \\
\hline $\begin{array}{l}\text { Hipertextualidade, pode-se afirmar ser uma } \\
\text { nova linguagem. (SI.1) } \\
\text { A proposta do encontro entre a era digital } \\
\text { com a escrita e a oralidade propiciado pelas } \\
\text { TICs traz ao educando uma comunicação } \\
\text { interativa, uma aprendizagem colaborativa e } \\
\text { o desenvolvimento da criatividade. (SI.3) }\end{array}$ & $\begin{array}{l}\text { O hipertexto viabiliza a } \\
\text { composição de múltiplas } \\
\text { linguagens. }\end{array}$ \\
\hline $\begin{array}{l}\text { Nesse novo universo a vinculação, a pesquisa } \\
\text { e a informação são requisitos básicos para que } \\
\text { se possa enriquecer e tornar a aprendizagem } \\
\text { significativa. (SI.2) } \\
\text { O hipertexto, na construção da pesquisa, repre- } \\
\text { senta agilidade e criatividade, pois há um alinha- } \\
\text { ve contextual entre as inúmeras alternativas; são } \\
\text { várias as possibilidades para construção de um } \\
\text { texto com introdução, desenvolvimento e con- } \\
\text { clusão. O usuário pode traçar caminhos nunca } \\
\text { antes imaginados, como se estivesse criando um } \\
\text { novo documento, de acordo com a associação } \\
\text { realizada através da interatividade, onde os di- } \\
\text { versos conhecimentos são concatenados, entre } \\
\text { si, de forma ágil. (SI.10) }\end{array}$ & $\begin{array}{l}\text { Os caminhos para a pesquisa } \\
\text { são ampliados com o } \\
\text { hipertexto. }\end{array}$ \\
\hline
\end{tabular}




\section{Quadro 4 - Questionamentos que sinalizam coerência com a proposta da atividade sobre o conteúdo estudado no fórum $A$ escrita e a leitura no hipertexto, do Módulo 4}

\begin{tabular}{|c|c|}
\hline Intervenções & Questionamentos \\
\hline $\begin{array}{l}\text { Como toda ferramenta, necessita da mediação } \\
\text { do professor habilitado para seu bom uso, } \\
\text { evitando assim que ao "navegar" o educando } \\
\text { fique "à deriva" e os objetivos didático- } \\
\text { pedagógicos se percam ao longo do caminho. } \\
\text { (SI.3) } \\
\text { É preciso que o professor seja mediador nesse } \\
\text { novo universo, na era digital, orientando a busca } \\
\text { por essa aprendizagem numa dimensão ampla, } \\
\text { em que o número de informações veiculadas } \\
\text { através do hipertexto é de grande significância. } \\
\text { O professor, portanto, deve mediar essa busca, } \\
\text { para que os fins primários não se percam, } \\
\text { deixando claro que as conexões estabelecidas } \\
\text { devem ancorar a aprendizagem. (SI.5) } \\
\text { Há um cuidado a ser considerado: a busca } \\
\text { incessante nas conexões, principalmente em } \\
\text { hipertextos mal organizados, pode provocar } \\
\text { o desvio do objetivo da pesquisa e a perda do } \\
\text { foco da leitura. (SI.6) }\end{array}$ & $\begin{array}{l}\text { No processo de ensino } \\
\text { e aprendizagem o uso do } \\
\text { hipertexto deve ser explorado } \\
\text { a partir de um planejamento, } \\
\text { com a mediação do } \\
\text { professor. }\end{array}$ \\
\hline $\begin{array}{l}\text { O hipertexto consideravelmente veio para } \\
\text { facilitar a leitura e possibilitar ao leitor } \\
\text { construir seu próprio percurso. (SI.7) } \\
\text { Frente à cultura digital, os processos de } \\
\text { alfabetização e letramento devem levar em } \\
\text { conta a diversidade das mídias existentes } \\
\text { de modo que a educação não se torne } \\
\text { ultrapassada, fora do seu tempo. (SI.7) } \\
\text { No âmbito escolar, a produção de textos dos } \\
\text { alunos deve ser significativa, pois o professor } \\
\text { deve considerar a importância de um suporte em } \\
\text { que se pode publicar sem intermediação, onde } \\
\text { o aluno pode ver seu texto lido por um público } \\
\text { autêntico, algo muito mais interessante do que } \\
\text { produzir textos apenas para o professor. (SI.8) } \\
\text { O computador mudou nossa maneira de ler, } \\
\text { construir e interpretar textos e isso tudo está } \\
\text { mudando nossa relação com a leitura. (SI.9) }\end{array}$ & $\begin{array}{l}\text { A alfabetização deverá mudar } \\
\text { com a influência da cultura } \\
\text { digital. }\end{array}$ \\
\hline
\end{tabular}




\section{Quadro 4 - Questionamentos que sinalizam coerência com a proposta da atividade sobre o conteúdo estudado no fórum $A$ escrita e a leitura no hipertexto, do Módulo 4}

\begin{tabular}{|c|c|}
\hline Intervenções & Questionamentos \\
\hline $\begin{array}{l}\text { O hipertexto eletrônico apresenta características } \\
\text { peculiares e vantajosas em relação ao material } \\
\text { inerte: possibilidade de interação com o texto; } \\
\text { facilidade de digitalização; disponibilidade para } \\
\text { publicação simultânea à escrita, aumentando } \\
\text { a rapidez na divulgação das informações e no } \\
\text { acesso ao conhecimento. (SI.6) }\end{array}$ & $\begin{array}{l}\text { Novos gêneros são compostos } \\
\text { no espaço digital. }\end{array}$ \\
\hline $\begin{array}{l}\text { A escola deve por outro lado ter outras } \\
\text { preocupações, a exemplo de propor novas } \\
\text { metodologias de ensino aprendizagem } \\
\text { ou simplesmente a viabilização de novas } \\
\text { linguagens que atendam as demandas da } \\
\text { sociedade atual e os anseios da juventude sem } \\
\text { correr o risco de ser considerada ultrapassada } \\
\text { e também de não deixar de cumprir sua função } \\
\text { social que é ensinar e com qualidade. (SI.1) }\end{array}$ & $\begin{array}{l}\text { O papel da escola deve } \\
\text { convergir para a prática do } \\
\text { letramento. }\end{array}$ \\
\hline $\begin{array}{l}\text { O letramento digital possibilita não apenas } \\
\text { novas formas de acesso à informação, mas } \\
\text { também novos processos cognitivos, novas } \\
\text { formas de conhecimento, novas maneiras de } \\
\text { ler e de escrever, enfim, um novo letramento, } \\
\text { isto é, um novo estado ou condição para } \\
\text { aqueles que exercem práticas de escrita e de } \\
\text { leitura na tela. (SI.8) }\end{array}$ & $\begin{array}{l}\text { Leitor e escritor revestem-se } \\
\text { de uma nova postura frente } \\
\text { ao letramento digital. }\end{array}$ \\
\hline
\end{tabular}

Através destas intervenções, observamos os sujeitos-informantes discutindo sobre a caracterização do letramento, inserindo-se sobre o campo que o conceitua e sua repercussão sobre a alfabetização e as modalidades de leitura e escrita. Pensando sobre a cultura digital, eles se voltam para rever suas práticas estando permeados no próprio processo que discute as mudanças na relação do ler e escrever diante das possibilidades do hipertexto. Na análise dessas novas possibilidades, os sujeitos-informantes orientam suas intervenções para as perspectivas que uma formação letrada integrada pelo uso das TICs vem favorecer à formação crítica dos sujeitos, destacando o papel da escola na execução desta proposta.

Nesse bloco de considerações temos a expressiva participação dos cursistas extrapolando a temática do fórum e levantando outras reflexões quanto ao uso das mídias. É possível observar que o entrelaçamento das ideias advém da análise das situações vivenciadas na escola em 
contrapartida com as possibilidades de converter os apontamentos teóricos na concretização de ações significativas, pontos estes que demarcam elementos de coerência com e sobre o conteúdo estudado.

No fórum Conectando, do Módulo 5 - Informática, as intervenções destacadas como sinalização de coerência são interpretadas na produção dos seguintes questionamentos (Quadro 5).

Quadro 5 - Questionamentos que sinalizam coerência com a proposta da atividade sobre o conteúdo estudado no fórum Conectando, do Módulo 5

(continua)

\begin{tabular}{|c|c|}
\hline Intervenções & Questionamentos \\
\hline $\begin{array}{l}\text { A escola deve realizar um trabalho educativo e } \\
\text { de permanente vigilância quanto a utilização da } \\
\text { internet, pois sabemos como se facilita também } \\
\text { a entrada em sites impróprios para crianças e } \\
\text { adolescentes. Normalmente, links viabilizam } \\
\text { esses caminhos. Desta forma, temos que } \\
\text { dialogar com nossos jovens sobre os benefícios } \\
\text { e os malefícios que ela nos leva. E com isso o } \\
\text { uso consciente desta ferramenta. (SI.2) } \\
\text { Com a questão atual de pedofilia, é importante } \\
\text { que a escola discuta junto aos pais dos alunos } \\
\text { sobre como seus filhos estão se comunicando } \\
\text { pela internet, se através de salas de bate-papos, } \\
\text { orkut, msn, ou outra forma de comunicação. } \\
\text { (...). Orientar o aluno no manuseio correto do } \\
\text { computador como componente físico. (SI.6) } \\
\text { Nossa preocupação em relação ao uso da internet } \\
\text { deve ser constante, temos que desenvolver } \\
\text { um trabalho consciente e transparente com } \\
\text { nossos alunos, os caminhos que podemos } \\
\text { trilhar nos dão margem a vários atalhos que } \\
\text { ajudarão a nossa prática de forma maciça e } \\
\text { transformadora. (SI.10) }\end{array}$ & $\begin{array}{l}\text { O professor deve orientar o } \\
\text { uso consciente da internet. }\end{array}$ \\
\hline $\begin{array}{l}\text { É necessário que se tenha, ao planejar uma } \\
\text { aula em laboratório de informática, objetivos } \\
\text { claros, a fim de evitar algum tipo de transtorno } \\
\text { no decorrer do evento. (SI.1) } \\
\text { Planejar a aula que fará uso da internet, } \\
\text { para evitar coisas do tipo que ocorreu com } \\
\text { nossa colega da disciplina de Português } \\
\text { (aluno disperso navegando em páginas } \\
\text { adultas!). Incentivar os alunos a acessarem } \\
\text { sites de conteúdos pedagógicos. (SI.6) }\end{array}$ & $\begin{array}{l}\text { As atividades pedagógicas a } \\
\text { serem desenvolvidas devem } \\
\text { ser planejadas. }\end{array}$ \\
\hline
\end{tabular}


Quadro 5 - Questionamentos que sinalizam coerência com a proposta da atividade sobre o conteúdo estudado no fórum Conectando, do Módulo 5

(continuação)

\begin{tabular}{l|l}
\multicolumn{1}{|c|}{ Intervenções } & \multicolumn{1}{c}{ Questionamentos } \\
\hline $\begin{array}{l}\text { A orientação pedagógica deve realizar } \\
\text { um trabalho metodológico para pesquisas } \\
\text { direcionadas aos objetivos específicos de cada } \\
\text { disciplina. Acrescentemos, ainda, a importância } \\
\text { da participação dos pais nesse processo } \\
\text { educativo. (SI.7) }\end{array}$ & \\
\hline $\begin{array}{l}\text { No âmbito escolar, deve-se explorar sua } \\
\text { utilização em pesquisas e desenvolvimento }\end{array}$ & \\
de projetos pedagógicos que culminem na \\
aplicação prática do conteúdo apreendido, \\
com atividades orientadas, supervisionadas e \\
estendidas ao ambiente familiar. (SI.9)
\end{tabular}


Quadro 5 - Questionamentos que sinalizam coerência com a proposta da atividade sobre o conteúdo estudado no fórum Conectando, do Módulo 5

(conclusão)

\begin{tabular}{|c|c|}
\hline Intervenções & Questionamentos \\
\hline $\begin{array}{l}\text { Tento ter cuidados ao visitar sites, assim como } \\
\text { a leitura de e-mails desconhecidos. (SI.2) } \\
\text { O cuidado em acessar a internet deve ser } \\
\text { constante e como professores devemos alertar } \\
\text { nossos alunos a terem o máximo de precaução, } \\
\text { acessando somente a sites confiáveis, usando } \\
\text { um bom antivírus, a fim de evitar algum tipo } \\
\text { de transtorno quanto ao uso em aplicações } \\
\text { educacionais, de relacionamentos e na troca } \\
\text { de conhecimentos. (SI.3) } \\
\text { Faz-se necessário algumas medidas de proteção } \\
\text { para seu uso seguro e eficiente, como: } \\
\text { ter sempre um bom antivírus instalado, } \\
\text { ativo e atualizado; nunca clicar em links de } \\
\text { e-mails sem conferir muito bem o destino do } \\
\text { mesmo; ter atenção redobrada nos arquivos } \\
\text { aparentemente inofensivos com anexos, pois } \\
\text { podem conter softwares maléficos com vírus, } \\
\text { troianos ou spywares. (SI.4) } \\
\text { O único meio seguro de utilização desses recursos } \\
\text { é fazer uso da ferramenta Backup de todas as } \\
\text { informações contidas no computador. (SI.6) } \\
\text { Possuir um antivírus atualizado, evitar abrir } \\
\text { arquivos executáveis que não sejam de } \\
\text { fonte conhecida, evitar fornecer números } \\
\text { de documentos pessoais, evitar acessos } \\
\text { históricos de navegação. (SI.7) }\end{array}$ & $\begin{array}{l}\text { É preciso ter alguns cuidados } \\
\text { para não deixar que a internet } \\
\text { seja uma porta aberta para a } \\
\text { deterioração do computador } \\
\text { pessoal. } \\
\text { É preciso ter um olhar } \\
\text { crítico sobre os conteúdos } \\
\text { disponibilizados na internet. }\end{array}$ \\
\hline
\end{tabular}

Neste estágio, os cursistas se debruçam em refletir sobre o uso da internet na educação, observando quais as possibilidades pedagógicas de utilizá-la como ferramenta de ensino e aprendizagem, e esboçam suas preocupações quanto ao uso banalizado, sem planejamento e objetivo norteador consistente. Ao se reconhecerem como sujeitos deste processo que utiliza a internet como recurso educacional, os cursistas exploram o fórum trocando experiências e apontando sugestões para um uso seguro e eficiente no contexto escolar.

É possível reconhecer no fórum um efetivo espaço de diálogo no qual os cursistas se comunicam em diversas direções; suas falas representam mais que respostas ao fórum, à medida que se ampliam para análise, 
avaliação, reflexão. Se focadas na categoria coerência, as postagens apresentam-se harmonicamente encadeadas, explorando o tema na esfera dos questionamentos e ampliando-se para as abordagens do dia a dia.

Concluindo com o fórum Estratégias articuladoras, do Módulo 6 - Gestão Integrada de Mídias na Educação, encontramos os cursistas expressando as seguintes intervenções geradoras dos questionamentos que sinalizam coerência com a proposta da atividade sobre o conteúdo estudado (Quadro 6).

Quadro 6 - Questionamentos que sinalizam coerência com a proposta da atividade sobre o conteúdo estudado no fórum Estratégias articuladoras, do Módulo 6

\begin{tabular}{|c|c|}
\hline Intervenções & Questionamentos \\
\hline $\begin{array}{l}\text { É necessário mudar nossas concepções acerca do } \\
\text { que é ensinar e aprender. A partir dessa reflexão } \\
\text { poderemos pensar e planejar projetos que } \\
\text { utilizem as TICs na escola com o intuito de discutir } \\
\text { o currículo escolar tendo como fundamento a } \\
\text { aprendizagem significativa e a articulação das } \\
\text { mídias no contexto escolar. (SI.1) }\end{array}$ & $\begin{array}{l}\text { É preciso rever as concepções } \\
\text { de ensino e aprendizagem. }\end{array}$ \\
\hline $\begin{array}{l}\text { Com o intuito de elaborar um planejamento } \\
\text { significativo em prol de uma aprendizagem } \\
\text { dinâmica, nada melhor do que ter como suporte } \\
\text { o recurso das tecnologias a fim de estabelecer } \\
\text { ações criativas para divulgar o conhecimento } \\
\text { produzido dentro da escola. (SI.4) } \\
\text { A integração das TICs em atividades } \\
\text { articuladas exige que os professores tenham } \\
\text { clareza das etapas a serem cumpridas e dos } \\
\text { objetivos pedagógicos a serem alcançados. } \\
\text { Selecionar muito bem o material de pesquisa, } \\
\text { indicando livros, revistas e páginas da web } \\
\text { para leitura ou programas de rádio e TV para } \\
\text { análise de debates a fim de orientar o estudo } \\
\text { dirigido. Estabelecer um horário semanal para } \\
\text { discussão, consolidação das idéias e devidas } \\
\text { conclusões. (SI.10) }\end{array}$ & $\begin{array}{l}\text { O planejamento é articulador } \\
\text { das ações. }\end{array}$ \\
\hline $\begin{array}{l}\text { É fundamental para o corpo escolar e } \\
\text { principalmente o professor conhecer os } \\
\text { recursos para que desta forma todos possam } \\
\text { ser envolvidos neste projeto desde a elaboração } \\
\text { até a conclusão, pois só assim o aprendizado } \\
\text { terá um significado real. (SI.2) }\end{array}$ & $\begin{array}{l}\text { A comunidade escolar } \\
\text { deve investir e valorizar a } \\
\text { integração das TICs. }\end{array}$ \\
\hline
\end{tabular}


Quadro 6 - Questionamentos que sinalizam coerência com a proposta da atividade sobre o conteúdo estudado no fórum Estratégias articuladoras, do Módulo 6

\begin{tabular}{|c|c|}
\hline Intervenções & Questionamentos \\
\hline $\begin{array}{l}\text { É necessário não só um investimento no } \\
\text { professor, mas também uma construção e } \\
\text { desenvolvimento democrático na escola. É } \\
\text { preciso propor estratégias viáveis e possíveis que } \\
\text { ajude na solução dos problemas que dificultam o } \\
\text { uso das TICs na comunidade escolar. (SI.8) }\end{array}$ & \\
\hline $\begin{array}{l}\text { Trabalhar com projetos é ter competência para } \\
\text { mudar o plano de atividades diante das novas } \\
\text { hipóteses sugeridas pelos alunos, levando em } \\
\text { conta que sua construção se dá através da relação } \\
\text { espontânea com os interesses da vida. (SI.6) } \\
\text { É evidente a importância de integrar as novas } \\
\text { tecnologias à pratica pedagógica para que } \\
\text { não fiquemos às margens do que acontece } \\
\text { na sociedade, já que esta evolui de forma tão } \\
\text { rápida. Fica claro também que só vale a pena } \\
\text { conhecer e aplicar recursos tecnológicos } \\
\text { na escola quando ela está envolvida num } \\
\text { projeto bem elaborado e integrado com toda } \\
\text { a comunidade escolar. (SI.7) } \\
\text { Na atualidade, a pedagogia de projetos ganha } \\
\text { força quando há reflexões sobre o papel da escola, } \\
\text { a sua função social e, principalmente, o significado } \\
\text { real das experiências escolares. (SI.10) }\end{array}$ & $\begin{array}{l}\text { A integração das TICs pode } \\
\text { ser contemplada junto ao } \\
\text { desenvolvimento de projetos } \\
\text { pedagógicos. }\end{array}$ \\
\hline $\begin{array}{l}\text { O WebQuesté uma boa estratégia principalmente } \\
\text { para os alunos e professores que não têm } \\
\text { vivência com uso das TICs, principalmente o } \\
\text { professor fornecendo uma lista de links a serem } \\
\text { pesquisados para que os alunos não fiquem } \\
\text { "perdidos" com o volume de informações de } \\
\text { que dispõem na internet. (SI.3) }\end{array}$ & $\begin{array}{l}\text { MetodologiascomoaWebQuest } \\
\text { tendem a valorizar o uso da } \\
\text { internet potencializando as } \\
\text { atividades de pesquisa. }\end{array}$ \\
\hline $\begin{array}{l}\text { O uso das TICs valoriza e inova o ensino- } \\
\text { aprendizagem, pois estes programas ajudam } \\
\text { o professor diversificar e desenvolver formas } \\
\text { construtivas de dinamizar os conteúdos, } \\
\text { levando os alunos a refletir sobre seu } \\
\text { aprendizado e suas produções. (SI.2) }\end{array}$ & $\begin{array}{l}\text { O uso das TICs pode viabilizar } \\
\text { a socialização das ações } \\
\text { pedagógicas. }\end{array}$ \\
\hline
\end{tabular}


Quadro 6 - Questionamentos que sinalizam coerência com a proposta da atividade sobre o conteúdo estudado no fórum Estratégias articuladoras, do Módulo 6

\begin{tabular}{|c|c|}
\hline Intervenções & Questionamentos \\
\hline $\begin{array}{l}\text { Uma das estratégias é logo após trabalhar com } \\
\text { projeto utilizando as mídias educativas propor } \\
\text { aos alunos que criem uma maneira criativa } \\
\text { para divulgar os saberes adquiridos utilizando } \\
\text { as TICs. (SI.4) }\end{array}$ & \\
\hline $\begin{array}{l}\text { Acho relevante observarmos o momento de } \\
\text { construção do projeto político-pedagógico da } \\
\text { escola, articulando os aspectos pedagógicos } \\
\text { e administrativos que envolvam as TICs. } \\
\text { Pois, esse projeto só toma significado quando } \\
\text { há participação de todos que compõem a } \\
\text { comunidade interna e externa à escola. (SI.5) }\end{array}$ & $\begin{array}{l}\text { O uso das TICs deve perpassar } \\
\text { o Projeto Político-Pedagógico } \\
\text { da escola articulando, desde } \\
\text { então, os aspectos pedagógicos } \\
\text { e administrativos. }\end{array}$ \\
\hline
\end{tabular}

Nesta última etapa do programa, os cursistas, com base nas leituras e nas experiências vivenciadas e conhecidas sobre o uso das TICs, dedicam-se à apresentação de possíveis estratégias e sugestões que possam ser utilizadas para integrá-las de forma articulada entre os aspectos pedagógicos e administrativos da escola. Como momento de conclusão, eles resgatam os fundamentos teórico-metodológicos discutidos ao longo dos outros cinco módulos e em reação à proposta do fórum.

Analisando o aspecto coerência em relação às respostas postadas e aos questionamentos do fórum, é possível observar a concordância das ideias no exercício de encadear as sugestões e estratégias para uso articulado das TICs no contexto educacional. Neste último módulo do programa, os sujeitos-informantes apresentam suas reflexões que retornam à literatura que fundamentou o curso, bem como se remetem à prática pedagógica que vivenciam na sua esfera escolar. Unindo estas duas vertentes, os sujeitos-informantes expressam um conhecimento elaborado em bases significativas que relaciona teoria e prática.

\section{Nível de letramento digital dos cursistas no uso de fórum de discussão}

Ao constatar a coerência na resposta dos sujeitos-informantes com a proposta de atividade sobre o conteúdo estudado, avançamos nossa análise no sentido de referendar se esta coerência de fato resulta da consulta do material de estudo. Para tanto, destacamos a categoria exploração de interação que perpassa o exercício do letramento digital. 
Nesta categoria é observado se nas intervenções postadas pelos sujeitosinformantes aparecem elementos que sinalizem a interação deles explorando os materiais do curso e interagindo com os outros cursistas. Assim sendo, apresentamos um quadro para análise dessas informações (Quadro 7).

\section{Quadro 7 - Elementos identificados nas intervenções postadas que sinalizam a exploração dos materiais do curso e a interação dos sujeitos-informantes com os outros cursistas}

\begin{tabular}{|c|c|c|}
\hline Fórum & $\begin{array}{c}\text { Elementos que sinalizam } \\
\text { consultas ao material do curso }\end{array}$ & $\begin{array}{c}\text { Elementos que } \\
\text { sinalizam a interação } \\
\text { com os outros cursistas }\end{array}$ \\
\hline $\begin{array}{l}\text { Refletindo } \\
\text { sobre a } \\
\text { mudança }\end{array}$ & $\begin{array}{l}\text { "Como o diz o texto de Manuel } \\
\text { Moran..." (SI. 3) } \\
\text { "O texto nos fala em..." (SI.3) } \\
\text { "Está bem claro que..." } \\
\text { "Nessa perspectiva, Castelles já dizia } \\
\text { em suas abordagens..." (SI.5) }\end{array}$ & $\begin{array}{l}\text { - Contribuição } \\
\text { - Argumentação } \\
\text { "Concordo com a sua } \\
\text { reflexão..." (SI.10) }\end{array}$ \\
\hline TV digital & Não houve ocorrências & $\begin{array}{l}\text { - Relato } \\
\text { - Contribuição } \\
\text { "Cara SI.2, } \\
\text { compactuo com seus } \\
\text { apontamentos..." } \\
\text { (SI.4) } \\
\text { - Explicação } \\
\text { "Olá Crs!" (SI.6) }\end{array}$ \\
\hline $\begin{array}{l}\text { Como } \\
\text { implantar } \\
\text { um projeto } \\
\text { pedagógico } \\
\text { com o rádio }\end{array}$ & $\begin{array}{l}\text { "Após o estudo deste módulo e } \\
\text { com as pesquisas desenvolvidas..." } \\
\text { (SI.1) } \\
\text { "(...) mas pretendo com a bagagem } \\
\text { que esta etapa do curso nos forneceu } \\
\text { através dos textos e sites que } \\
\text { vinculam estas experiências, realizar } \\
\text { alguns projetos é claro adaptando } \\
\text { algumas metas, objetivos e ações." } \\
\text { "Agora possuo maiores informações } \\
\text { sobre como utilizar o rádio na } \\
\text { escola..." (SI.2) } \\
\text { "Ao fazer a leitura do módulo li } \\
\text { várias experiências..." (SI.4) }\end{array}$ & $\begin{array}{l}\text { - Contribuição } \\
\text { - Relato } \\
\text { - Explicação } \\
\text { "As experiências dos } \\
\text { meus colegas nos faz } \\
\text { perceber o quanto o } \\
\text { módulo nos dá várias } \\
\text { possibilidades de como } \\
\text { utilizar o rádio em } \\
\text { nossas escolas..." (SI.5) } \\
\text { "Cursistas, cada um } \\
\text { de nós pode ser o } \\
\text { princípio de um grande } \\
\text { projeto..." (SI.6) }\end{array}$ \\
\hline
\end{tabular}




\section{Quadro 7 - Elementos identificados nas intervenções postadas que sinalizam a exploração dos materiais do curso e a interação dos sujeitos-informantes com os outros cursistas}

(conclusão)

\begin{tabular}{|c|c|c|}
\hline Fórum & $\begin{array}{c}\text { Elementos que sinalizam } \\
\text { consultas ao material do curso }\end{array}$ & $\begin{array}{c}\text { Elementos que } \\
\text { sinalizam a interação } \\
\text { com os outros cursistas }\end{array}$ \\
\hline $\begin{array}{l}\text { A escrita e } \\
\text { a leitura no } \\
\text { hipertexto }\end{array}$ & $\begin{array}{l}\text { "Quando falamos em hipertexto } \\
\text { visualizamos uma dimensão } \\
\text { planetária, onde as conexões } \\
\text { começam a esboçar a inteligência } \\
\text { coletiva de que nos fala Pierre } \\
\text { Lévy." (SI.3) } \\
\text { "No artigo 'Hipertexto como } \\
\text { instrumento para apresentação } \\
\text { de informações em ambiente de } \\
\text { aprendizado mediado pela internet', } \\
\text { Cristina Portugal cita que, de acordo } \\
\text { com Rezende (2003), Ausubel } \\
\text { (1963) afirma que o homem pensa } \\
\text { de forma não linear." (SI.6) } \\
\text { "Como bem discorre Xavier } \\
\text { (2004)..." (SI.7) } \\
\text { "Como comentou Georg Simmel } \\
\text { (1987), em seu artigo A metrópole } \\
\text { e a vida mental..." (SI.10) }\end{array}$ & $\begin{array}{l}\text { - Contribuição } \\
\text { - Relato } \\
\text { - Questionamento } \\
\text { - Argumentação } \\
\text { "(...) o que vocês } \\
\text { acham?" (SI.4) } \\
\text { "Caros colegas, pode- } \\
\text { se aferir que..." (SI.5) } \\
\text { "Abraços a todos." } \\
\text { (SI.9) }\end{array}$ \\
\hline Conectando & Não houve ocorrências & $\begin{array}{l}\text { - Contribuição } \\
\text { - Relato } \\
\text { - Argumentação } \\
\text { "Como fala dos } \\
\text { demais..." (SI.2) }\end{array}$ \\
\hline $\begin{array}{l}\text { Estratégias } \\
\text { articuladoras }\end{array}$ & Não houve ocorrências & $\begin{array}{l}\text { - Contribuição } \\
\text { - Relato } \\
\text { "Não muito diferente } \\
\text { da realidade da colega } \\
\text { Cursista." (SI.7) } \\
\text { "Olá Crs! Concordo } \\
\text { quando você diz } \\
\text { que..." (SI.8) } \\
\text { - Contra- } \\
\text { argumentação }\end{array}$ \\
\hline
\end{tabular}


Observando a incidência das intervenções que sinalizam a interação dos sujeitos-informantes com o material do curso, é possível verificar como o diálogo nesta esfera é limitado. Apesar da maioria das respostas serem coerentes com a proposta do fórum, tal como constatamos na análise anterior, poucos cursistas apontam em suas intervenções a origem da sua fundamentação teórica, fazendo referência ao material consultado que embasou a produção daquele conhecimento descrito.

Diante deste posicionamento dos sujeitos-informantes, interpretamos a produção das intervenções como produto de três situações: a) houve consulta do sujeito-informante ao material e ele cita a fonte de sua intervenção; b) houve consulta do sujeito-informante ao material, mas ele não cita diretamente nem indiretamente a fonte - a consulta será refletida pelos elementos e informações contidos no material que são retomados na intervenção do sujeito-informante; c) não houve consulta do sujeito-informante ao material - a sua intervenção é fundamentada nos conhecimentos prévios que já detém.

Para o primeiro e o segundo caso, entendemos que, na perspectiva do letramento alfabético, a coerência na resposta dos sujeitos-informantes com a proposta de atividade corresponde de fato ao estudo e compreensão dos conteúdos dos módulos. Na perspectiva do letramento digital, sinaliza o desempenho de habilidades referentes ao acesso e manuseio de suporte e gêneros digitais, à medida que acessaram o AVA, localizaram o conteúdo do módulo e os manusearam através da leitura hipertextual.

Para o terceiro caso, entendemos que, na perspectiva do letramento alfabético, apesar da coerência na resposta dos sujeitos-informantes com a proposta de atividade, ela não corresponde ao estudo e compreensão dos conteúdos do módulo, mas resultam da sistematização dos conhecimentos prévios sobre o conteúdo abordado. Na perspectiva do letramento digital, não é observado o desempenho de habilidades referentes ao acesso e manuseio de suporte e gêneros digitais, uma vez que não houve consulta ao material de estudo. Interpretamos que a não consulta ao material pode ter sido fruto de três situações: 1) o sujeito-informante não quis acessar o material e preferiu postar suas intervenções com base nos seus conhecimentos prévios; 2) o sujeito-informante não sabia como localizar o conteúdo do módulo e/ ou manuseá-lo através da leitura hipertextual; 3) o sujeito-informante teve dificuldade de localizar o conteúdo do módulo e/ou manuseá-lo através da leitura hipertextual.

Para este contexto, observamos a fragilidade das intervenções. Se na perspectiva do letramento alfabético o uso do fórum corresponde às expectativas, no sentido de compreensão do tema abordado, na perspectiva do letramento digital a expectativa do exercício do letramento digital é comprometida mediante a não garantia de consulta ao material de estudo.

Diante dessas situações, constata-se que as práticas leitoras e escritoras imersas no programa Mídias na Educação estão intrinsecamente ligadas ao letramento alfabético e ao letramento digital, de modo 
que a análise do letramento alfabético é de ordem cognitiva (envolve compreensão do material consultado) e a do letramento digital é de ordem operacional (implica a verificação das habilidades para navegar no AVA, as que dizem respeito ao acesso e manuseio do material do curso). Logo, a deficiência e/ou dificuldade no exercício dessas habilidades pode incidir na qualidade das interações.

Quanto à incidência das intervenções que sinalizam a interação com os outros cursistas, são observadas algumas demonstrações de diálogo, nas quais, direta ou indiretamente, os cursistas evidenciam estar se comunicando entre si, remetendo-se às ideias apresentadas pelo outro para concordar ou contrapor suas reflexões. Todavia, as marcas de diálogo ainda são exibidas de forma tímida e igualmente limitada. Ainda que os próprios sujeitos-informantes reconheçam o fórum como um espaço de troca, compartilhamento e comunicação, conforme declararam no questionário aplicado, não atuam integralmente nesta perspectiva. Em geral as suas participações se restringem a uma postagem respondendo à proposta do fórum; poucos desdobram as reflexões dos colegas fazendo inferências e travando um real diálogo.

Diante desse comportamento dos sujeitos-informantes, interpretamos que o exercício do letramento digital não se desenvolveu integralmente no que se refere ao uso do fórum, pois, apesar de identificarem a função do fórum como ferramenta de interação assíncrona e espaço de diálogo, não efetivam as suas intervenções neste sentido - minimamente questionam sobre o conteúdo estudado e/ou sobre as intervenções dos outros cursistas. É possível considerar que o pouco conhecimento por parte dos cursistas quanto à dinâmica de interação no fórum, posto que 60\% nunca haviam interagido em fórum de discussão, seja um dos indicadores que influenciaram no desenvolvimento das interações.

A necessidade de cumprirem o cronograma das atividades - que, em média, era de sete dias para a realização de cada atividade - e a obrigatoriedade da participação refletiram também no uso do fórum, influenciando o uso dele como espaço apenas de depósito das intervenções, sem maiores desdobramentos nas interações.

Outros indicadores podem estar relacionados à existência de interatividade quando esta implica o uso das ferramentas para propagação dos diálogos.

A categoria existência de interatividade trata da acessibilidade e usabilidade do fórum. Buscamos saber como a esfera estrutural do fórum é utilizada pelos sujeitos-informantes, se existem aspectos e/ou ferramentas que dificultam ou favorecem a interação.

O fórum acessado no perfil cursista é apresentado por três campos (Fig. 4):

$\left.1^{\circ}\right)$ Espaço de orientação ao cursista, que apresenta a temática do fórum, indicando o responsável pela abertura e as respectivas data e hora da criação. 
$2^{\circ}$ ) Espaço de pesquisa, onde o cursista pode consultar informações referentes às postagens filtrando-as por autor, período, mensagem, temas (procurar por), delimitando ainda o número de mensagens por página.

$3^{\circ}$ ) Apresenta a consignação a ser desenvolvida; nela os cursistas encontram a proposta do fórum e orientam as suas reflexões. Esta primeira mensagem é normalmente postada pelo responsável do fórum. Sob o tópico de introdução é gerado um link que permite a interação dos cursistas. A cada nova mensagem postada é gerado um link no tópico principal que oportuniza a interação sob as respectivas mensagens.

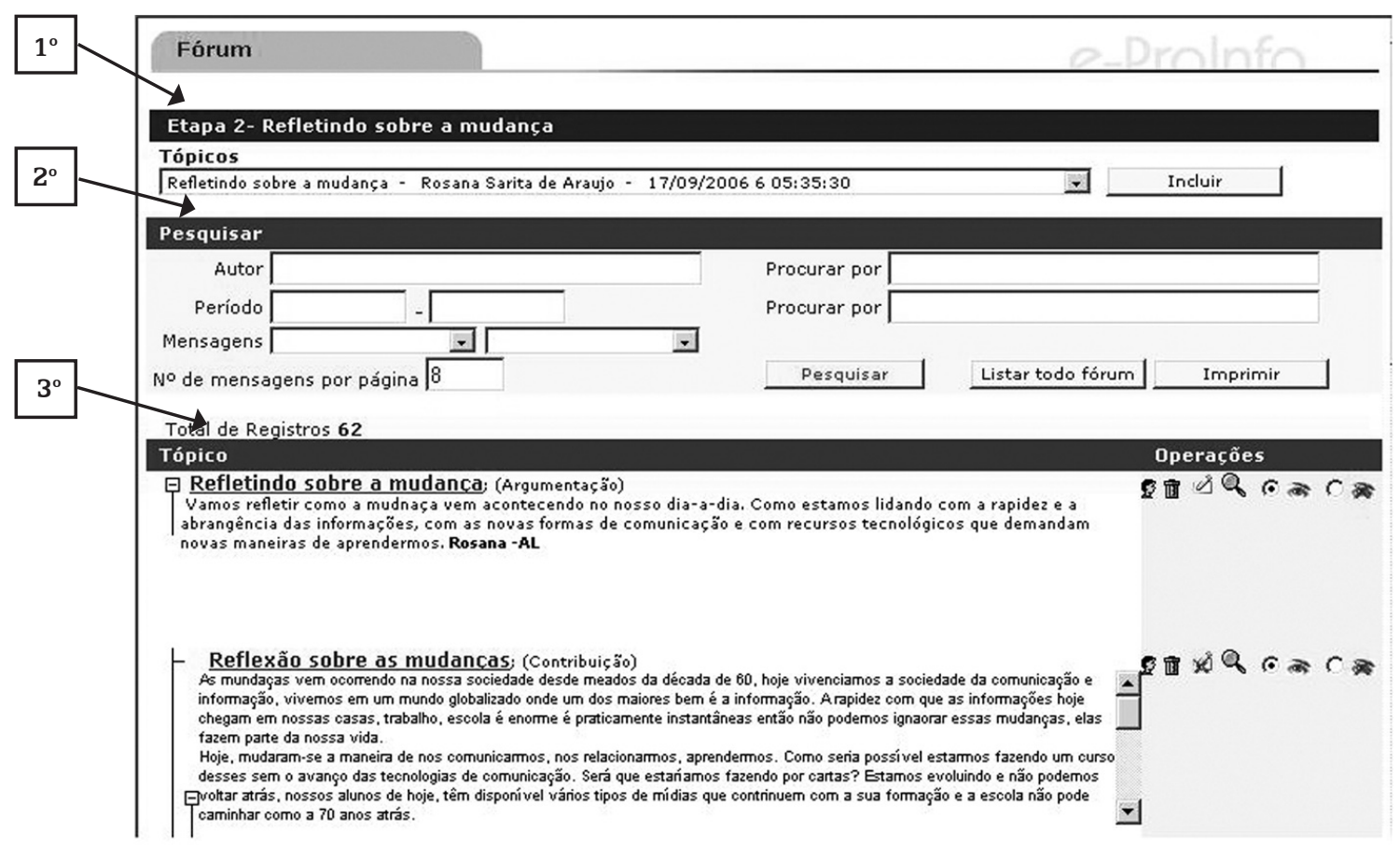

Figura 4 - Campos do fórum de discussão

Do ponto de vista estrutural, o fórum é arquitetonicamente aprovado pelos sujeitos-informantes, posto não descreverem dificuldades relacionadas a acessibilidade e usabilidade de acesso e uso das ferramentas. As vantagens e desvantagens do fórum apontadas pelos sujeitos-informantes no questionário remetem-se aos aspectos de ordem pedagógica e não estrutural e técnica.

Dentro dos parâmetros de vantagens, os cursistas pontuam o fórum como uma ferramenta assíncrona eficiente, uma vez que permite a comunicação direta entre os participantes, possibilitando a troca de ideias e experiências, de modo que os diálogos podem ser mais bem elaborados. Estando acessível em qualquer tempo, é um espaço de construção coletiva. 
Quanto às desvantagens do fórum, em razão de o tempo de postagem ser aberto, observa-se que pode haver atraso nas participações e que estas podem ser superficiais por parte dos cursistas que não interagem com os outros participantes. Neste sentido, o ritmo das interações pode ser prejudicado.

De acordo com estes indicativos, constatamos que o nível de letramento digital dos cursistas, no que se refere à exploração das ferramentas do fórum quanto à acessibilidade e usabilidade, é positivamente avaliado quando demonstram o domínio das habilidades necessárias para exploração deste espaço sem comprometer a qualidade do processo de interação.

As três categorias analisadas - existência de coerência na resposta do cursista com a proposta de atividade sobre o conteúdo estudado, exploração da interação e existência de interatividade -, apesar de estarem inter-relacionadas, não desencadeiam habilidades remetentes ao letramento digital de forma linear. Constatamos que o nível de letramento digital para cada uma dessas habilidades é independente quando, na amostra analisada, detectamos na categoria de interação um baixo nível de letramento digital (nível 1 - uso mecânico e condicionado, ainda não reconhece integralmente as propriedades do gênero digital), enquanto na categoria de interatividade detectamos um nível regular de letramento digital (níveis 2 e 3 - compreensão sobre o funcionamento e estruturação das ferramentas e desenvoltura no seu uso).

\section{Considerações finais}

Analisar as implicações do letramento digital nas interações on-line favorece o desenvolvimento qualitativo da educação on-line, porque avalia as especificidades desta modalidade de educação preocupando-se com uma estrutura sustentável que venha oferecer reais condições para o processo de ensino e aprendizagem.

Os aspectos do letramento digital que se aplicam à educação on-line precisam ser analisados considerando as propriedades que se estabelecem no contexto digital. Estes aspectos estão sendo amadurecidos com o aperfeiçoamento da internet e a evolução das TICs.

Este estudo destacou o uso do fórum de discussão, que, por ser um espaço aberto de diálogo, tem sido uma ferramenta de grande popularização. E não diferente por esta característica, a educação on-line recorre à sua utilização objetivando travar entre os sujeitos envolvidos no processo de ensino e aprendizagem relações cada vez mais próximas do diálogo presencial.

Todavia, ao observar as intervenções dos cursistas, ficamos incomodados por, num primeiro momento, não reconhecermos a efetivação dos diálogos e/ou visualizá-los de forma tímida e limitada, e logo nos questionamos se aqueles resultados teriam, a priori, relação com o nível de letramento digital dos cursistas. Assim, levantamos o 
seguinte problema: Como o nível de letramento digital do cursista, em suas interações, interfere nos fóruns de discussão do programa Mídias na Educação?

Na tentativa de investigar a problemática, os estudos se concentraram em: descrever as características do fórum de discussão e as habilidades necessárias para nele interagir qualitativamente; categorizar os níveis (ou graus) de letramento digital em fórum de discussão a partir do domínio de habilidades necessárias para o uso desta ferramenta de interação online; analisar o nível de letramento digital apresentado pelos cursistas nos fóruns do programa Mídias na Educação.

No que se refere ao primeiro objetivo, o referencial teórico destacou as características do fórum enquanto suporte, identificando-o como espaço de interação assíncrona que possibilita a aprendizagem colaborativa, e enquanto gênero digital, no qual os diálogos podem ser organizados através do entrelaçamento das diversas intervenções postadas.

Quanto ao segundo objetivo, categorizamos os níveis de letramento digital para uso do fórum em nível 1, nível 2 e nível 3. Os parâmetros para cada nível foram embasados no domínio de habilidades específicas para uso do fórum.

O terceiro objetivo concentrou o foco da pesquisa sendo desenvolvido desde a coleta, sistematização e análise dos dados. Seu desdobramento culminou na socialização dos resultados alcançados.

Cada um desses objetivos orientou a constituição do referencial teórico que norteou a apreciação dos dados coletados, dando subsídio para a análise dos aspectos e categorias envolvidos no uso do fórum. Esses objetivos consideram o aspecto existência de coerência na resposta do cursista com a proposta de atividade sobre o conteúdo estudado e as categorias que caracterizam o letramento digital: interação e interatividade.

Apesar do aspecto existência de coerência na resposta do cursista com a proposta de atividade sobre o conteúdo estudado ser de origem cognitiva, entendemos ser pertinente a sua análise, uma vez que seu processamento subsidia as condições de interação no fórum. Precisávamos verificar três situações: 1 - a resposta do sujeito-informante é coerente, logo ele tinha condições de interagir; 2 - a resposta do sujeito-informante é incoerente, logo ele tinha dificuldade de interagir; 3 - não há resposta do sujeito-informante, logo ele não interagiu.

Na análise, constatamos que os sujeitos-informantes apresentam sim coerência em suas respostas, que estão de acordo com as propostas de atividades e os conteúdos sugeridos para estudo, na medida em que os questionamentos produzidos pelas intervenções remetem-se às temáticas abordadas e incidem sobre os objetivos das atividades.

Se tivéssemos detectado a falta de coerência nas respostas ou ausência de resposta, interpretaríamos estas como um indicativo, na perspectiva do letramento alfabético, de dificuldade de compreensão de ideias e inferência das informações. Seria o reflexo de que os sujeitos-informantes em algum momento interagiram com dificuldade ou não interagiram, por não terem conhecimento dos temas/conteúdos abordados. 
Na perspectiva do letramento digital, interpretaríamos como indicativo de dificuldade de acesso ou não acesso ao material, ações relacionadas ao exercício de práticas e eventos de letramento digital, tais como o acesso aos materiais de estudo disponibilizados na internet, o uso de ferramentas de interação e o contato com gêneros digitais.

A questão seria: se a resposta do sujeito-informante é incoerente ou ele não responde, é porque não tem conhecimento do tema/conteúdo. Para ter conhecimento ele poderia ter acessado o material do curso. Então, por que ele não acessou ou teve dificuldade no acesso? A resposta para esta questão poderia ser: o sujeito-informante não acessou os conteúdos por opção, ou o sujeito-informante teve dificuldades no acesso aos conteúdos, ou o sujeito-informante não acessou os conteúdos porque não sabia.

Se considerados os dois últimos casos, verificamos que o acesso com dificuldade ou não acesso é uma situação que reflete diretamente o nível de letramento digital do sujeito-informante. Neste caso, o baixo nível de letramento iria interferir nas interações, acarretando interações com dificuldade ou a não interação por parte do sujeito-informante.

Mas como todos os resultados apontaram a existência de coerência na resposta do cursista com a proposta de atividade sobre o conteúdo estudado, constatamos que este aspecto não foi influenciado pelo nível de letramento digital, já que todos os sujeitos-informantes demonstraram condições de interagir.

Avançando para a categoria interação, verificamos duas situações: a primeira relacionada à consulta do material e a segunda relacionada à interação entre os sujeitos-informantes. Em ambas interpretamos a influência do nível de letramento digital.

No que se refere à consulta do material, os resultados apontam que, na perspectiva do letramento digital, houve desempenho, por parte de alguns sujeitos-informantes, de habilidades referentes ao acesso e manuseio de suporte e gêneros digitais, já que acessaram o AVA, localizaram os conteúdos dos módulos e os manusearam através da leitura hipertextual. Estas habilidades foram constatadas através de fragmentos das intervenções que sinalizavam consultas ao material do curso.

Todavia, verificou-se que poucos cursistas apontavam em suas intervenções a origem da sua fundamentação teórica, fazendo referência ao material consultado que embasou a produção daquele conhecimento descrito. Interpretamos que a não consulta ao material pode ter sido fruto de três situações já apresentadas: o sujeito-informante não quis acessar o material e preferiu postar suas intervenções com base nos seus conhecimentos prévios; o sujeito-informante não sabia como localizar os conteúdos dos módulos e/ou manuseá-los através da leitura hipertextual; o sujeito-informante teve dificuldade de localizar os conteúdos dos módulos e/ou manuseá-los através da leitura hipertextual.

Quanto à interação com os outros cursistas, entendemos ser esta uma categoria-chave que delineia o nível de letramento digital. A possibilidade de interação é um dos avanços da educação on-line, pois pretende estabelecer um canal de diálogo entre as partes envolvidas. O letramento 
digital, ao envolver novas práticas de leitura e escrita, atrela a estas habilidades as portas da interação, pois é através destes novos suportes que a informação e a comunicação podem ser processadas.

De acordo com os resultados do questionário aplicado, constatamos que a maioria dos sujeitos-informantes não tinha experiência em fóruns de discussões; $60 \%$ das respostas apontaram falta de familiarização com interação em fórum. Este resultado pode ser um dos indicadores da pouca interação travada entre os sujeitos-informantes.

Verificamos nas intervenções dos sujeitos-informantes elementos que sinalizassem a interação entre os cursistas; os resultados apontaram poucos registros com indícios de diálogo e apenas algumas intervenções refletiam uma tentativa de comunicação direta ou indiretamente.

Chamou-nos a atenção o fato de que, ao final do curso, os sujeitosinformantes já detinham um conhecimento sobre as especificidades do fórum de discussão. Ainda que anteriormente não tivessem experiência com o fórum, com o decorrer do programa interiorizaram a sua funcionalidade enquanto suporte, reconhecendo-o como um ambiente propício à interação.

Todavia, ainda que progressivamente os sujeitos-informantes tenham reconhecido o fórum como espaço de diálogo, na prática não utilizaram suas potencialidades explorando suas vias de comunicação. De modo geral as participações se restringem a uma postagem respondendo a proposta do fórum. Observamos que a necessidade de cumprirem o cronograma das atividades e a obrigatoriedade da participação podem ser outros indicativos que justifiquem a pouca interação.

Analisamos, portanto, que o nível de letramento dos sujeitosinformantes interferiu na categoria interação. Houve um baixo nível de letramento digital (nível 1 - uso mecânico e condicionado, ainda não reconhece integralmente as propriedades do gênero digital), constatado mediante os poucos sinais de diálogo entre os sujeitos-informantes explorando a interação.

Enquanto o primeiro aspecto analisado indicava que os sujeitosinformantes tinham condições de interagir, pois suas respostas eram coerentes, e o segundo, que reconheciam a função do fórum como espaço de diálogo, buscamos verificar se a interatividade poderia ser mais um aspecto a interferir na interação.

$\mathrm{Na}$ categoria interatividade as respostas em geral foram remetidas aos aspectos de ordem pedagógica, destacando as vantagens e desvantagens do fórum. No que se refere ao aspecto estrutural, o fórum é arquitetonicamente aprovado pelos sujeitos-informantes, posto não descreverem dificuldades relacionadas a acessibilidade e usabilidade de acesso e uso das ferramentas. Fica explícito que sabem utilizar as ferramentas do fórum ou pelo menos têm domínio da ferramenta básica para postagem de intervenções, já que os registros apontam a participação de todos os sujeitos-informantes.

Os resultados apontam que na categoria de interatividade houve um nível regular de letramento digital (níveis 2 e 3 - compreensão sobre o 
funcionamento e estruturação das ferramentas e desenvoltura no seu uso), na medida em que os sujeitos-informantes demonstram o domínio das habilidades necessárias para exploração do fórum. Observa-se, portanto, que o nível de letramento digital dos sujeitos-informantes nesta categoria vem também influir no processo interações.

Diante dos resultados apontados retomamos a nossa hipótese, a qual pressupunha que o nível de letramento digital do cursista interfere na dinâmica e na qualidade de sua interação nos fóruns de discussão, de modo que, quanto maior for seu letramento digital, mais relevantes serão suas intervenções. Com o apoio das análises concluímos que:

- o nível de letramento digital interfere sim na dinâmica das interações nos fóruns de discussão, pois as habilidades relacionadas às categorias interação e interatividade estão relacionadas com o nível de letramento digital do cursista para desenvolvê-las - a primeira no sentido de reconhecer o fórum como um espaço de diálogo e nele interagir; a segunda no sentido de saber utilizar as ferramentas do fórum para efetivar a sua interação;

- o nível de letramento digital não interfere na qualidade das interações nos fóruns de discussão, pois este é um aspecto relacionado ao letramento alfabético - a qualidade das interações está relacionada à capacidade cognitiva de compreensão de ideias e inferência a partir de informações;

- quanto maior for o nível de letramento digital do cursista, mais possibilidades de interagir nos fóruns de discussão ele apresentará, por conhecer as especificidades de interação no fórum e dominar suas ferramentas de interação;

- quanto maior for o letramento alfabético do cursista, mais possibilidades há de as suas intervenções serem relevantes.

De acordo com estas conclusões, verificamos que nossa hipótese foi parcialmente confirmada, pois o nível de letramento digital do cursista interfere na dinâmica de sua interação nos fóruns de discussão, enquanto o letramento alfabético influi na qualidade das interações.

Essas constatações foram possíveis seguindo o encadeamento metodológico da etnografia virtual. Subsidiando o resgate e análise dos registros on-line, esse encadeamento apontou o fórum como um campo de relações, fundamentando assim a compreensão do processamento das relações nele desenvolvidas.

Entendendo a internet como um espaço de interação social, a etnografia virtual orientou a investigação no sentido de observar como as práticas que nela se desdobram se tornam significativas no contexto social. Logo, observando as implicações do nível de letramento digital dos cursistas nas interações nos fóruns, compreendemos como este espaço é por eles percebido e utilizado.

Esperamos que os resultados desta investigação venham incidir sobre o desenvolvimento do programa Mídias na Educação, observando a necessidade de reforçar o fórum como um efetivo espaço de diálogo. Neste sentido, os tutores, sondando o nível de letramento dos cursistas, devem 
implementar ações que favoreçam a interação no fórum, diagnosticando se as dificuldades de interação são de origem cognitiva ou se estão relacionadas ao nível de letramento digital. Acreditamos que a atuação na perspectiva de melhorar a dinâmica das interações também favorecerá a utilização do fórum como uma das ferramentas de avaliação dos cursistas.

Por fim, reconhecendo a extensão da temática letramento digital e a imaturidade dos estudos sobre os aspectos referentes aos níveis de letramento digital, identificamos que os resultados desta pesquisa instigam a elaboração de novos questionamentos que podem despontar da observação do nível de letramento digital a partir de outras categorias, aspectos e habilidades.

\section{Referências bibliográficas}

ALMEIDA, Maria E. B. Educação, ambientes virtuais e interatividade. In: SILVA, Marcos (Org.). Educação online. São Paulo: Loyola, 2003.

. Letramento digital e hipertexto: contribuições à educação. In: SCHLÜNZEN JUNIOR, Klaus (Org.). Inclusão digital: tecendo redes afetivas/cognitivas. Rio de Janeiro: DP\&A, 2005.

BAKHTIN, Mikhail. Estética da criação verbal. 2. ed. São Paulo: Martins Fontes, 1997.

BRUNO, Adriana R; HESSEL, Ana M. Os fóruns de discussão como espaço de aprendizagem em ambientes on-line: formando comunidade de gestores. In: CONGRESSO INTERNACIONAL DE EDUCAÇÃO A DISTÂNCIA, 13., 2007, Curitiba. Anais do... Curitiba, Abed: 2007. Disponível em: <http://www.abed.org.br/congresso2007/ tc/420200712027PM.pdf>. Acesso em: 8 fev. 2008.

BUZATO, Marcelo E. Letramentos digitais e formação de professores. In: CONGRESSO IBERO-AMERICANO EDUCAREDE, 3., 2007, São Paulo. [Anais do III Congresso...]: educação, internet e oportunidade. São Paulo: Cenpec, 2007. p. 80-91. Mesa redonda: Educação e Internet: a formação do professor-autor. Disponível em: <http://www.educarede.org.br/educa/ img_conteudo/MarceloBuzato.pdf>. Acesso em: 8 fev. 2008.

CHARTIER, R. A aventura do livro: do leitor ao navegador. São Paulo: Unesp, 1999.

COSTA, Roberto S. (Hiper)textos ciberespaciais: mutações do/no ler-escrever. Cadernos Cedes, Campinas, v. 25, n. 65, p. 102-116, jan./abr. 2005. 
COSTA, Roberto S. A construção/apropriação da escrita nas salas de aula da escola fundamental e nas salas de bate-papo na internet. Delta, São Paulo, v. 22, n. 1, p. 159-175, 2006. Disponível em: <www.scielo. br/pdf/delta/v22n1/31734.pdf>.

CUNHA, Fernando; PAIVA, João. A utilização de fóruns em contexto de ensino/aprendizagem. In: CONFERÊNCIA INTERNACIONAL DE TECNOLOGIA DE INFORMAÇÃO E COMUNICAÇÃO NA EDUCAÇÃO - CHALlENGE, 3., 2003, Braga, Portugal. [Anais da III Conferência...] e $5^{\circ}$ Simpósio Internacional em Informática Educativa. Braga, 2003. p. 25-47. Disponível em: www.nonio-uminho.pt/ challenges/05comunicacoes/Tema1/03FernandoCunha.pdf. Acesso em: 20 maio 2007.

DIAS, Ângela A.; MOURA, Karina S. O fio do dialogismo na (re) construção do conhecimento em rede: uma concepção bakhtiniana dos processos na comunicação na prática pedagógica. In: SANTOS, Edimea; ALVES, Lynn (Orgs.). Práticas pedagógicas e tecnologias digitais. Rio de Janeiro: E-papeis, 2006. p. 77-90.

FORTUNATO, M. V. Autoria sob materialidade do discurso. 2003. Dissertação (Mestrado em Educação) - Universidade de São Paulo (USP), 2003.

HEATH, Shirley B. What "no bedtime story" means: narrative skills at home and school. Language in Society, v. 11, n. 1, p. 49-76, 1982.

HINE, Christine. Etnografia virtual. Barcelona: UOC, 2004.

KLEIMAN, Ângela B. Os significados do letramento: uma nova perspectiva sobre a prática social da escrita. Campinas: Mercado das Letras, 1995.

LINDEN, Marta M.; PICONEZ, Stela C.; ANDRÉ, Cláudio F. O uso de fórum num espaço híbrido de aprendizagem: reflexões sobre os processos de avaliação e acompanhamento da interação em fórum on-line. In: CONGRESSO INTERNACIONAL DE EDUCAÇÃO A DISTÂNCIA, 13., 2007, Curitiba. [Anais...]. Curitiba: Abed, 2007. Disponível em: <http://www.abed.org.br/congresso2007/trabalhos. asp> Acesso em: 8 fev. 2008.

MARCUSHI, Luiz A.; XAVIER, Antônio C. Hipertexto e gêneros digitais: novas formas de construção do sentido. Rio de janeiro: Lucerna, 2004.

MORAN, José M. Contribuições para uma pedagogia da educação online. In: SILVA, Marcos (Org.). Educação online: teorias, práticas, legislação, formação corporativa. São Paulo: Loyola, 2003. p. 39- 50. 
QUEIROZ, Rita de. A informação escrita: do manuscrito ao texto virtual. In: ENCONTRO NACIONAL DE CIÊNCIA DA INFORMAÇÃO (Cinform), 6., 2005, Salvador (BA). Proceedings... 2005. Disponível em: < http:// www.cinform.ufba.br/vi_anais/docs/RitaQueiroz.pdf>.

RAMAL, Andréa C. Ler e escrever na cultura digital. Disponível em: $<$ http://www.revistaconecta.com/destaque/edicao04.htm>. Acesso em: 24 fev. 2002.

RIBEIRO, Vera M. (Org.). Letramento no Brasil. 2. ed. São Paulo: Global, 2004.

RIBEIRO, Ana E. Texto e leitura hipertexual: novos produtos, velhos processos. Linguagem \& Ensino, Pelotas, v.9, n.2, p. 13-32, jul./dez. 2006.

RICARDO, Eleonora J.; VILARINHO, Lúcia R. A construção da autoria na aprendizagem online: um desafio da pós-graduação. Revista Brasileira de Pós-Graduação, Brasília, v. 3, n. 5, p. 59-78, jun. 2006.

Práticas educacionais e tecnologias de informação e comunicação: potencializando a autoria do aluno on-line. In: SANTOS, Edimea; ALVES, Lynn (Orgs.). Práticas pedagógicas e tecnologias digitais. Rio de Janeiro: E-papeis, 2006. p. 107-122.

ROJO, Roxane; BARBOSA, Jacqueline P.; COLLINS, Heloisa. Letramento digital: um trabalho a partir dos gêneros do discurso. In: KARWOSKI, Acir M.; GAYDELZKA, Beatriz; BRITO, Karim S. (Orgs.). Gêneros textuais: reflexões e ensino. 2. ed. Rio de Janeiro: Lucerna, 2006. p.107-130.

SILVA, Marcos. Educação online. São Paulo: Loyola, 2005.

. Educação e Internet: a formação do professor-autor. In: CONGRESSO IBERO-AMERICANO EDUCAREDE, 3., 2007, São Paulo. [Anais do III Congresso...]: educação, internet e oportunidade. São Paulo: Cenpec, 2007. Mesa redonda: Educação e Internet: a formação do professor-autor. Disponível em: http://projetos.educarede.info/ iiicongresso/iiicongresso_livro.pdf. Acesso em: 08 fev. 08.

SOARES, Magda. Letramento "um tema em três gêneros". 2. ed. Belo Horizonte: Autêntica, 2000.

Novas práticas de leitura e escrita: letramento na cibercultura. Educação \& Sociedade, Campinas, v. 23, n. 81, p. 143-160, dez. 2002. Disponível em: <http://www.cedes.unicamp.br>. Acesso em: 20 maio 2006. 
SOARES, Magda. Letramento e escolarização. In: RIBEIRO, Vera M.

(Org.). Letramento no Brasil. 2. ed. São Paulo: Global, 2004. p. 89-113.

TFOUNI, Leda V. Letramento e alfabetização. São Paulo: Cortez, 1995.

XAVIER, Antonio C. Letramento digital e ensino. 2002. Disponível em: $<$ www.ufpe.br/nehte/artigos/Letramento-digital-Xavier.pdf>. Acesso em: 20 maio 2006.

Luís Paulo Leopoldo Mercado, doutor em Educação pela Pontifícia Universidade Católica de São Paulo (PUC-SP), é professor associado II do Programa de Pós-Graduação em Educação da Universidade Federal de Alagoas e pesquisador na área de Educação a Distância e Tecnologias da Informação e Comunicação na Educação.

lpmercado@oi.com.br

Rosana Sarita de Araújo, mestre em Educação pela Universidade Federal de Alagoas (Ufal), é professora das redes de ensino estadual de Alagoas e municipal de Maceió.

rosasarita@hotmail.com

Recebido em 10 de agosto de 2009.

Aprovado em 15 de dezembro de 2009. 